MACIEJ GÓRNY

Instytut Historii im. Tadeusza Manteuffla PAN

\title{
KARTY NA STÓŁ. GEOGRAFIA I GRANICE NOWEJ EUROPY PO I WOJNIE ŚWIATOWEJ
}

\begin{abstract}
Abstrakt: Tematem artykułu jest udział geografów w dyskusji nad nowymi granicami Europy Środkowo-Wschodniej i Południowo-Wschodniej w czasie I wojny światowej i na konferencji pokojowej w Paryżu. Na przykładzie uczonych takich jak Jovan Cvijić, Eugeniusz Romer, Stepan Rudnic'kyj i Viktor Dvorský autor analizuje strategie argumentacyjne towarzyszące tworzeniu definicji terytorium narodowego. W dalszej części tekstu zajmuje się wpływem ekspertów geograficznych na ustalenia konferencji pokojowej w Paryżu w 1919 r.
\end{abstract}

Słowa kluczowe: geografia, terytorium, I wojna światowa, konferencja pokojowa w Paryżu, granice.
Abstract: The article discusses the contribution of geographers to the discussion about the new boundaries of East-Central and South-Eastern Europe during the First World War and the peace conference at Paris. Using the examples of such scholars as: Jovan Cvijić, Eugeniusz Romer, Stepan Rudnytskyi and Viktor Dvorský, the author analyses the argumentative strategies used to formulate the definition of national territory. In the further part of the text he focuses on the contribution of experts in geography to the output of the Paris Peace Conference of 1919.

Keywords: geography, territory, First World War, Paris Peace Conference, borders.

W grudniu 1914 r., cztery miesiące po rozpoczęciu działań wojennych, londyńskie Royal Geographical Society zorganizowało dyskusję poświęconą potencjalnym terytorialnym skutkom konfliktu. Profesor miejscowego uniwersytetu, Lionel W. Lyde, wystąpił z referatem, w którym sklasyfikował typy europejskich granic. Punktem wyjścia był dla niego podział etniczny, w przypadku idealnym umożliwiający prostą delimitację dwóch terytoriów narodowych. Rzeczywistość jednak rzadko obdarza nas tak klarownym podziałem, fundamentalny czynnik etniczny wymagał więc uzupełnienia o inne wyznaczniki. Tu Lyde, idąc za Friedrichem Ratzlem, 
krytycznie odniósł się do tradycyjnych linii granicznych, na przykład poprowadzonych wzdłuż rzek. Ich strategiczne znaczenie malało wraz z rozwojem techniki i transportu, dlatego odpowiedzialni mężowie stanu powinni, jego zdaniem, myśleć raczej o pasach niż o liniach granicznych. W idealnym przypadku państwa powinny być rozdzielone przez pustynie lub bagna, ewentualnie wysokie góry albo nieprzebyte morze. Takich granic nie spotyka się jednak zbyt często, w szczególności zaś trudno o nie w gęsto zaludnionej Europie. Wobec wszystkich tych trudności Lyde sformułował trzy zasady, którymi winni się kierować twórcy Europy przyszłości. Po pierwsze, granice powinny w miarę możności obejmować terytorium zajmowane przez ludy, które nie podlegają łatwej asymilacji (za taki uważał na przykład Albańczyków). Po drugie, jeśli już państwo obejmuje więcej narodowości, musi posiadać zdolność do ich asymilowania (ten warunek z kolei przemawiał w jego opinii na niekorzyść niemieckich podbojów). Po trzecie, granice nie powinny dzielić, czego i tak nie są $\mathrm{w}$ stanie zrobić skutecznie. W zamian należy je przeprowadzać w miejscach, które w sposób naturalny łączą ludzi. Do takich zaliczył Lyde rzeki, na przykład Ren, oraz niskie góry. Odstępstwa od tych zasad dopuszczał tam, gdzie przemawiały za nimi względy strategiczne ${ }^{1}$.

Słuchacze podeszli do rozważań Lyde'a dość sceptycznie. Spencer Wilkinson, historyk wojskowości, zgłosił sporo uwag szczegółowych, okraszając je ironiczną uwagą: „Wystarczy zebrać kilku profesorów geografii i dać im dyskutować kwestie etniczne i znajdziemy się w zupełnie innym miejscu, niż byśmy chcieli" 2 . Wiele zastrzeżeń do idei naturalnych granic zgłosił także jeden z pionierów geopolityki, Halford Mackinder. Poza uwagami natury geograficznej odwołał się także do zdrowego rozsądku, zwracając uwagę, że i dawniej, i dziś granice wyznacza się w procesie negocjacji, a nie ustalania prawdy naukowej3.

Dalszy przebieg wojennych wypadków zrodził pytanie, czy rzeczywiście wkład geografów w proces tworzenia nowych granic Europy był aż taki skromny. Czy mężowie stanu, podejmujący najważniejsze decyzje, używali map i opracowań dostarczanych przez naukowców jedynie do ilustracji podjętych wcześniej postanowień oraz po to, by mieć na czym oprzeć łokcie podczas przeciągających się rozmów? W historiografii I wojny światowej i paryskiej konferencji pokojowej coraz częściej zwraca się uwagę na rolę ekspertów, specjalistów w kwestiach tak istotnych dla

${ }^{1}$ L.W. Lyde, Types of Political Frontiers in Europe, „The Geographical Journal” 45, 1915, 2, s. 126-139.

2 Ibidem, zapis dyskusji, s. 139-145, cyt. s. 141: „As soon as you get Professors of Geography talking about race they may take us a very long way further than we want to go".

3 Ibidem, s. 142. 
polityki międzynarodowej jak ekonomia, demografia, prawo czy geografia $^{4}$. Uwaga badaczy skupia się przy tym na ekspertach wielkich mocarstw. Niniejszy artykuł poświęcony będzie ich mniej znanym kolegom, członkom delegacji „małych” państw Europy Środkowo-Wschodniej, przede wszystkim przedstawicielom nauk geograficznych. Jak należy oceniać ich wkład w decyzje konferencji i w jaki sposób próbowali te decyzje kształtować?

\section{Wojenne bestsellery}

Przyszłe granice Europy pozostawały popularnym tematem akademickich sporów mniej więcej przez trzy pierwsze lata Wielkiej Wojny ${ }^{5}$. Większość wypowiedzi uczonych, poświęconych temu tematowi, miała charakter przyczynkarski bądź na poły amatorski. Na tym tle wyróżniały się dokonania trzech geografów z Europy Środkowo- i Południowo-Wschodniej: Stepana Rudnic'kiego (Степан Рудницький, Stepan Rudnic'kij), Jovana Cvijićia i Eugeniusza Romera.

W 1910 r. Rudnic’kyj złożył w wydawnictwie „Łan” w Kijowie rękopis popularnej geografii Ukrainy, pionierskie dzieło definiujące i opisujące kraj bez państwa. Polityczny potencjał tego wydarzenia zapewne łatwiej będzie sobie uświadomić, wiedząc, że zaledwie trzynaście lat wcześniej ukazała się w ogóle pierwsza profesjonalna mapa etnograficzna Ukrainy, autorstwa Hryhorija Wełyczki (Григорій Величко, Grigorij Weličko), z opisami w języku ukraińskim ${ }^{6}$. Ambicją Rudnic'kiego było w równej mierze ugruntowanie wiedzy rodaków o ojczyźnie, jak i upodmiotowienie narodu ukraińskiego ${ }^{7}$. Pierwszy tom ukazał się jeszcze w tym samym

${ }^{4}$ Zob. m.in. T. Ter Minassian, Les géographes français et la délimitation des frontières balkaniques à la conférence de la paix en 1919, „Revue d'histoire moderne et contemporaine” 44, 1997, 2, s. 252-286; G. Sluga, The Nation, Psychology, and International Politics, 1870-1919, Basingstoke 2006; G. Palsky, Emmanuel de Martonne and the Ethnographical Cartography of Central Europe (1917-1920), „Imago Mundi” 54, 2002, s. 111-119; N. Ginsburger, Réseaux académiques et circulations savantes entre guerres et paix (1912-1919). Les expertises de Jovan Cvijić et de ses collègues géographes à travers les cas de Trieste et Fiume, „Cybergeo. European Journal of Geography" 2016, https://cybergeo.revues.org/27690 (dostęp: 24 VI 2018).

5 Zob. M. Górny, Wielka Wojna profesorów. Nauki o człowieku (1912-1923), Warszawa 2014, s. 126-150.

${ }^{6}$ І. Ровенчак, Фактори та джерела видання Г. Величком „Народописної карти українсько-руського народу" в 1896 р., w: Картографія та історія України. Збірник наукових праць, red. Я. Дашкевич et al., Львів 2000, s. 109-118.

7 O politycznych ambicjach Rudnic'kiego zob. G. Hausmann, Das Territorium der Ukraine. Stepan Rudnyc'kyjs Beitrag zur Geschichte räumlich-territorialen Diskurs über die Ukraine, w: Die Ukraine. Prozesse der Nationsbildung, red. A. Kappeler, Wien 2011, s. 145-157. 
roku pod tytułem Korotka heohrafija Ukrainy (Коротка географія України). Rudnic'kyj nie był z niego zadowolony, w książce roiło się bowiem od błędów. Nie była to jednak najgorsza sprawa. Wkrótce po ukazaniu się pierwszego tomu wydawca poinformował autora, że drugą część pracy zgubił. Ten, wciąż jeszcze licząc na odnalezienie rękopisu, czekał dłuższy czas, aż w końcu, zrezygnowany, napisał książkę na nowo i złożył do druku w wydawnictwie lwowskiego Towarzystwa im. Szewczenki ${ }^{8}$. Praca ukazała się ostatecznie w roku 1914 i mało kto zdążył się z nią zapoznać przed wkroczeniem do Lwowa armii rosyjskiej. Rosjanie z kolei natychmiast pozamykali ukraińskie organizacje i gazety, zakazując dystrybucji książek w języku, którego nie uznawali. Rudnic'kyj znalazł się na uchodźstwie z połową swojego dzieła wydanego tak niedbale, że wstyd mu było chwalić się nim przed kolegami z branży.

Zdolny uczeń Albrechta Pencka z okresu jego berlińskiej profesury całą swą wiedzę fachową podporządkował dowodzeniu, że Ukraina stanowi byt odrębny pod każdym względem. Przeszłość Ukrainy to ciągła walka z obcymi najazdami, co sprawia, że to właśnie jej należy się chwalebny tytuł przedmurza chrześcijaństwa. Przede wszystkim stwierdził, że zamieszkujący ją ludzie przynależą do rasy odrębnej od Polaków i od Rosjan:

Z owych badań [chodzi o antropologiczne prace Izydora Kopernickiego, Juliana Talki-Hryncewicza i Hwedira Wowka (Hvedìr Vovk, Fëdor Volkov) M.G.] wypływa wniosek, że Ukraińcy są wprawdzie pod względem antropologicznym mieszanką rasową [--]. Ale mieszanka owa ukształtowała się w bardzo odległej, prehistorycznej przeszłości, a późniejsze przymieszki okazały się zbyt słabe, aby wpłynąć na pierwotny typ rasowy Ukraińców. Od Wisłoki aż po Kubań i od Prypeci aż po Morze Czarne lud ukraiński należy do jednorodnego typu antropologicznego?.

Ów typ zaliczał Rudnic'kyj do tak zwanej rasy dynarskiej, charakteryzującej się ciemną pigmentacją (barwą oczu i włosów), wysokim wzrostem, okrągłą czaszką. Zgodnie ze stanem ówczesnej wiedzy antropologicznej, najbliższych rasowych pobratymców Ukraińców należało szukać

${ }^{8}$ I. Stebelski, Putting Ukraine on the Map. The Contribution of Stepan Rudnyts'kyi to Ukrainian Nation-Building, „Nationalities Papers” 39, 2011, 4, s. 587-613, tu s. 594.

9 „Die Ukrainer sind nach diesen Untersuchungen zwar auch eine anthropologische Mischrasse [--]. Aber die Bildung dieser Mischrasse ist in einer sehr entfernten vorhistorischen Vergangenheit vor sich gegangen und spätere Beimischungen sind nur geringfügig gewesen, um den ursprünglichen Rassentypus der Ukrainer merklich verändern zu können. Vom Wýssłok bis zum Kubánj, von der Prýpjatj bis zum Schwarzen Meere bildet das ukrainische Volk einen einheitlichen anthropologischen Typus", S. Rudnyćkyj, Ukraina. Land und Volk. Eine gemeinfassliche Landeskunde, Wien 1916, s. 178. 
na Bałkanach ${ }^{10}$. Bezpośredni sąsiedzi - Rosjanie i Polacy - oczywiście nie mieli z Bałkanami nic wspólnego. Rudnic'kyj umieszczał ich dość nisko w hierarchii ras, a to za sprawą przymieszki fińskiej i mongolskiej krwi. Od niepochlebnych ocen ważniejszy był jednak wniosek geopolityczny: „Polak, Białorusin, Rosjanin są pod względem antropologicznym bardzo do siebie zbliżeni, Ukrainiec różni się zasadniczo od wszystkich swoich sąsiadów i zajmuje z perspektywy antropologii zupełnie osobne stanowisko"11. Tę różnicę chłop ukraiński miał odczuwać instynktownie, zwłaszcza w stosunku do Rosjan. Rudnic'kyj nie obawiał się zatem rusyfikacji, chociaż podkreślał fałszerstwa rosyjskich spisów ludności. Zresztą asymilacja do narodów sąsiednich nie była dla Ukraińca szczególnie atrakcyjna, skoro, jak zauważał geograf, „każdy nieuprzedzony obserwator musi przyznać, że chłop ukraiński [--] wyrasta ponad swoich sąsiadów dzięki wrodzonym zdolnościom"12.

Biorąc pod uwagę polityczny ciężar tych teorii, trudno się dziwić, że ukraiński geograf zdecydował się opuścić Lwów wraz z wycofującą się armią austro-węgierską. Właściwa recepcja jego pracy zaczęła się właściwie dopiero wówczas, gdy wraz z innymi uciekinierami z Galicji Wschodniej dotarł do Wiednia. Tu sam przełożył swoją pracę na język niemiecki, najpierw jednak przygotował wersję skróconą, zawierającą te same tezy z okrojonym materiałem dowodowym i ilustracyjnym ${ }^{13}$. Ta esencjonalna, bezkompromisowa książka została następnie przełożona na włoski, węgierski, angielski, czeski i rosyjski. W końcu w 1916 r., nakładem Związku Wyzwolenia Ukrainy (Sojuz Wyzwolennija Ukrajiny, Bund zur Befreiung der Ukraine) ukazała się również pełna wersja w języku niemieckim, przełożona następnie na francuski i angielski ${ }^{14}$. Rudnic'kyj w tym czasie niestrudzenie przygotowywał kolejne mapy i publikacje, dostarczając naukowych argumentów ukraińskim działaczom politycznym w Wiedniu i w Berlinie ${ }^{15}$. Korzystał przy tym ustawicznie ze swojej

10 M. Górny, Bone \& Soul. Physical Anthropology, the Great War and Nationalism in Eastern Europe, „Cuadernos de historia contemporánea” 36, 2014, s. 239-258.

11 „Der Pole, der Weißrusse, der Russe stehen anthropologisch einander sehr nahe, der Ukrainer ist von allen seinen Nachbarn sehr verschieden und nimmt anthropologisch betrachtet eine ganz selbständige Stellung ein", S. Rudnyćkyj, Ukraina. Land und Volk, s. 182.

12 ,jeder vorurteilsloser Beobachter muß zugeben, daß der ukrainische Bauer [- - ] durch seine natürlichen Fähigkeiten alle seine Nachbarn überragt”, ibidem, s. 263.

13 S. Rudnyćkyj, Ukraina und die Ukrainer, Wien 1914.

${ }^{14}$ I. Stebelski, op. cit., s. 595.

${ }^{15}$ Bibliografia wojennych prac Rudnic'kiego znajduje się w jego biografii: П. Штойко, Степан Рудницкий 1877-1937. Життеписно - бібліографічний нарис, Львів 1993, s. $159-163$. 
najdłuższej monografii, kondensując jej przesłanie w coraz krótszych i coraz popularniejszych formach ${ }^{16}$. Z tego samego źródła czerpali także inni ukraińscy publicyści oraz ich niemieccy i austriaccy sojusznicy ${ }^{17}$. W większej części kryptocytatem z prac Rudnic'kiego była m.in. odezwa Związku Wyzwolenia Ukrainy, opublikowana w 1915 r. w Monachium ${ }^{18}$. Co istotniejsze dla politycznych interesów ukraińskich emigrantów, prace geografa spotkały się z dobrym przyjęciem niemieckich kolegów po fachu ${ }^{19}$, a cytaty i parafrazy najważniejszych fragmentów książki Rudnic'kiego trafiły także do opracowań niemieckojęzycznych autorów, pragnących przybliżyć rodakom sytuację na Wschodzie. Tuż po oficjalnym uznaniu ukraińskiej państwowości przez Rzeszę w traktacie brzeskim, w Berlinie ukazało się dzieło zbiorowe, opisujące najnowszego sojusznika Niemiec. Sporządzona przez Maximiliana W. Meyera-Heydenhagena charakterystyka rasowa jego mieszkańców jest wyraźnym świadectwem daleko idących zapożyczeń z Rudnic'kiego: „Nawet jeśli Ukraińcy stanowią mieszankę rasową z przewagą pierwiastka słowiańskiego, to w każdym razie są odrębną, dawną mieszanką, która różni się zasadniczo od mieszanki polskiej albo rosyjskiej. Nie są ani spolonizowanymi Rosjanami, ani zrusyfikowanymi Polakami, ani tym bardziej Słowiano-Mongołami, jak Rosjanie"20.

Jeszcze bardziej spektakularną drogę przeszedł w czasie wojny lwowski kolega i rywal Rudnic'kiego, Eugeniusz Romer. Już opracowany przezeń w 1904 r. podręcznik geografii dla galicyjskich szkół został obłożony zakazem dystrybucji w Prusach, jako ziemie polskie traktował bowiem nie tylko zabór pruski, ale także Górny Śląsk. Dużo poważniejsze reperkusje wywołał Geograficzno-statystyczny atlas Polski z roku 1916. Co istotne,

16 Na przykład S. Rudnyćkyj, Der östliche Kriegsschauplatz, Jena 1915; idem, Zur Landes- und Volkskunde der Ukraine, „Osteuropäische Zukunft” 1, 1916, 22, s. 347-351 oraz 2, 1917, 1, s. 1-15.

17 Na przykład L. Cehelskyj, Die großen politischen Aufgaben des Krieges im Osten und die ukrainische Frage, Berlin 1915.

${ }^{18}$ Die Ukraine und der Krieg. Denkschrift des Bundes zur Befreiung der Ukraine, München 1915.

19 Por. H. Hassinger, Zu Landeskunde Osteuropas. Rudnyćkyjs Werk über die Ukraina, „Zeitschrift der Gesellschaft für Erdkunde zu Berlin” 1918, s. 246-251; M. Friederichsen, rec.: St. Rudnyćkyj, Ukraina. Land und Volk, „Dr. A Petermanns Mitteilungen aus Justus Perthes' Geographischer Anstalt” 63, 1917, 10, s. 314-315.

20 „Sind aber die Ukrainer somit eine Mischrasse, in der das slawische Element überwiegt, so bilden sie doch jedenfalls eine eigenartige alte Mischung, die von der polnischen oder der russischen Mischung vollkommen verschieden ist. Sie sind weder polonisierte Russen noch russifizierte Polen, noch weniger sind sie Slawo-Mongolen wie die Russen", Ukraina, red. H. Lenz, Berlin 1918, s. 22. 
opisy map sporządzono w nim zarówno po polsku, jak i po niemiecku oraz francusku, a Romer osobiście zadbał o popularyzację wyników swojej pracy na Zachodzie ${ }^{21}$. Wszystkie legendy i komentarze umieszczone na mapach także zostały podane po polsku, niemiecku i francusku. Pod względem zastosowanych metod atlas zwracał uwagę szeroką skalą użycia izarytm na mapach przedstawiających stosunki etniczne, gęstość zaludnienia i stosunki gospodarcze. Metoda przenoszenia danych statystycznych na mapę opierała się na interpolacji, czyli uśrednieniu wartości skrajnych. Romer dysponował danymi ludnościowymi dla jednostek terytorialnych (w tym wypadku jednostek wielkości powiatu, opracowanych przez statystyków państw zaborczych). Aby przedstawić stosunki ludnościowe, na przykład gęstość zaludnienia, mógłby oznaczyć każdą z nich zgodnie z posiadanymi danymi odpowiednim kolorem bądź odcieniem. Zamiast tego geograf zdecydował się zilustrować przejścia pomiędzy poszczególnymi wartościami, granice zaznaczając $\mathrm{w}$ miejscu znajdującym się w takim oddaleniu od stolicy powiatu, które odpowiadało różnicy gęstości zaludnienia pomiędzy nim a powiatem sąsiednim. Ten sposób pozwalał przybliżyć się do wartości realnych i przynajmniej częściowo uwalniał geografów od konieczności reprodukowania granic administracyjnych nawet $\mathrm{w}$ przypadku zjawisk, które $\mathrm{z}$ administracją państwową nie mają związku²2.

Dzieło miało olbrzymi ciężar polityczny, dostrzeżony natychmiast zarówno przez zwolenników, jak i przeciwników polskiego ruchu narodowego. W rzeczy samej, datowane na koniec grudnia 1915 r. Uwagi ogólne polskiego geografa (czyli wstęp do publikacji) nie pozostawiały złudzeń co do politycznych ambicji atlasu: „Ta ilustracja mowy cyfr o Polsce i Polakach niech uczy swoich, a budzi rozwagę i życzliwość u tych, w ręku których spoczywają losy sprawy polskiej. Wszak cyfry wskazują, jak rządzić światem!”.

Polityczne zaangażowanie Romera wywoływało gwałtowne reakcje. Stosunki łączące go z Albrechtem Penckiem, kiedyś serdeczne, rozluźniły się już na przełomie XIX i XX w., najpierw na tle różnic naukowych, a następnie światopoglądowych. W 1913 r., kiedy na kongresie kartograficznym w Paryżu Niemiec przedstawił swoje mapy Śląska (przynależącego do Niemiec nie tylko via facti, ale i, jak utrzymywał,

${ }^{21}$ E. Romer, Poland. The Land and the State, „Geographical Review” 4, 1917, 1, s. 6-25; J. Saryusz [E. Romer], La Pologne. Le Sol et l'Etat, Lausanne 1915.

22 M. Labbé, Eugene Romer's 1916 Atlas of Poland. Creating a new Nation-State, „Imago Mundi" 70, 2018, 1, s. 93-113; L. Barwińska, Metoda izarytmiczna w mapach ludnościowych i społeczno-gospodarczych Eugeniusza Romera, „Polski Przegląd Kartograficzny” 3, 1971, 3, s. $97-105$. 
mocą praw historycznych), stosunki obu uczonych stały się wręcz lodowate $^{23}$. Niełaska dawnego nauczyciela miała dla Romera nieprzyjemne skutki. W 1916 r., kiedy niemieckie władze okupacyjne uruchamiały polski uniwersytet w Warszawie, Penck stanowczo zaprotestował przeciw powołaniu lwowskiego profesora na stołeczną katedrę geografii. W korespondencji z generalnym gubernatorem Hansem Beselerem wyraził żal, że niepoprawny nacjonalizm Polaków prawdopodobnie udaremniłby nominację najlepszego - jego zdaniem - kandydata, czyli Stepana Rudnic'kiego ${ }^{24}$. W liście do Josepha Partscha pisał z kolei:

Warszawiacy zaproponowali Eugeniusza Romera i [Ludomira] Sawickiego na profesorów geografii. Mam wątpliwości co do obydwu. Mówiąc między nami, uważam Romera za niebezpiecznego polskiego szowinistę o miernych zdolnościach. Sawickiego stawiam znacznie wyżej pod względem naukowym, ale jego niezdecydowanie i powierzchowność nie wywarły na mnie dobrego wrażenia. W dodatku byłem świadkiem tego, jak odkrył swoje polskie serce, a przecież wychował się jako prawdziwy wiedeńczyk. [--] Tak czy owak Romer musi, w naszym niemieckim interesie, zostać absolutnie wykluczony ${ }^{25}$.

Tak też się stało: ani Romer, ani Sawicki nie otrzymali warszawskiej katedry. Pozostała formalnie nieobsadzona, a zajęcia ze studentami prowadził Stanisław Lencewicz, świeżo upieczony doktor po studiach w Neuchâtel w Szwajcarii. Tytuł profesora zwyczajnego uzyskał dopiero na początku lat dwudziestych, po przeprowadzeniu procedury habilitacyjnej na lwowskim uniwersytecie, pod czujnym okiem Romera. Działo się to już jednak poza wiedzą i wpływem niemieckich kolegów.

Po ukazaniu się w Wiedniu polskiego atlasu Penck powiadomił niemiecki sztab generalny o rzekomej zdradzie stanu Romera. Wskutek

23 S. Seegel, Mapping Europe's Borderlands. Russian Cartography in the Age of Empire, Chicago-London 2012, s. 249.

${ }^{24}$ BJ, Rękopisy, Materiały, Eugeniusz Romer, sygn. d. 325, List do Beselera, kwiecień 1916.

25 „Die Warschauer haben Eugen v. Romer und Savicki für die Geographie-Professur vorgeschlagen. Gegen beide hege ich Bedenken. Romer halte ich, im Vertrauen gesagt, für einen recht gefährlichen Grosspolen von geringer Leistungsfähigkeit. Savikki stelle ich wissenschaftlich erheblich höher; aber es tat mir seine zunehmende Flüchigkeit und Oberflächigkeit keinen guten Eindruck hinterlassen. Auch war ich Zeuge, wie er sein polnisches Herz entdeckte, nachdem er als echter Wiener aufgewachsen war. [--] Aber Romer muss in unserem deutschen Interesse entschieden ausser Frage bleiben”, List Pencka do Partscha, 2 III 1916, cyt za: N. Ginsburger, „«La guerre, la plus terrible des érosions». Cultures de guerre et géographes universitaires AllemagneFrance-Etats-Unis (1914-1921)", thèse pour obtenir le grade de Docteur de l'Université Paris Ouest Nanterre-La Défense, 2010, s. 528. 
niemieckich nacisków Romer musiał istotnie stanąć przed austriackim sądem, który jednak oczyścił go z zarzutów, uznając atlas za dzieło stricte naukowe. Zakazano jednak wywozu publikacji poza granicę ${ }^{26}$. Blokada okazała się na tyle skuteczna, że aż do zakończenia I wojny światowej atlas recenzowali wyłącznie specjaliści polscy, niemieccy i austriaccy. Entuzjastyczne recenzje w fachowych czasopismach francuskich i anglosaskich miały pojawić się dopiero później.

Najciekawiej wśród tych wczesnych, niemieckojęzycznych recenzji atlasu przedstawia się bez wątpienia omówienie, które ukazało się w połowie 1918 r. na łamach „Geographische Zeitschrift”. Autor, Max Friederichsen, bez sympatii odniósł się do politycznej tendencji atlasu. Przyjęcie granic z 1772 r. jako punktu wyjścia do prac statystycznych i kartograficznych uznał za niedorzeczność, projekcję radykalnego nacjonalizmu Romera. Z tego względu uważał dzieło za szkodliwe, gdyż zamiast mitygować polskie nastroje, podbijało bębenek narodowej tromtadra$\mathrm{cji}^{27}$. Wszystkie te zastrzeżenia kończyły się jednak w momencie, gdy recenzent przechodził od omówienia tendencji politycznych do poziomu technicznego atlasu. Tu jedna pochwała goniła drugą, nawet jeśli niekiedy wydawało się, że z trudem przechodzą przez zaciśnięte zęby piszącego. Mapy Romera okazały się przejrzyste, wygodne w użytkowaniu, a decyzja o rozszerzeniu terytorium poddanego badaniom poza Kongresówkę przyniosła ciekawe efekty. Friederichsen dostrzegał zalety nawet w kwestii najbardziej kontrowersyjnej, czyli w sposobie przedstawienia stosunków etnicznych:

Wśród przygotowanych przez samego E. Romera map etnicznych, stanowiących bez wątpienia główny trzon atlasu, na podkreślenie zasługuje tablica VII, ponieważ w nowatorski metodologicznie sposób, przy użyciu tzw. „izarytm” uzyskanych dzięki interpolacji (metoda stosowana także w innych partiach atlasu!), oferuje jasny, dobrze odpowiadający całokształtowi stosunków fizycznych i antropogeograficznych, obraz gęstości zaludnienia ${ }^{28}$.

${ }^{26}$ S.M. Brzozowski, Eugeniusz Mikołaj Romer, PSB, t. 31, Wrocław 1989, s. 635-645, tu s. 639.

${ }^{27}$ M. Friederichsen, rec.: Eugenius v. Romer, Geographisch-statistischer Atlas von Polen, „Geographische Zeitschrift” 24, 1918, 5-6, s. 190-191.

28 „Unter den ausschließlich von E. von Romer selber bearbeiteten völkischen Karten, welche fraglos das Schwergewicht des Atlas darstellen, verdient Tafel VII deswegen Hervorhebung, weil sie in methodisch neuartiger Darstellung, unter Benutzung von durch Interpolation gewonnenen sog. «Isarithmen» (eine auch sonst im Atlas häufig verwendete Methode!) ein klares, der Gesamtheit der physischen und anthropogeographischen Verhältnisse gut gerecht werdendes Bild der Bevölkerungsdichte bietet", ibidem, s. 191. 
W podobnym tonie wypowiadali się geografowie austriaccy. W recenzji na łamach „Kartographische und schulgeographische Zeitschrift” wiedeński profesor Hugo Hassinger, skądinąd niemiecki nacjonalista, pisał:

I choć można w tym [wyborze granic z 1772 r. - M.G.] widzieć tendencję polityczną, od której niewolna jest także zamieszczona $\mathrm{w}$ atlasie mapa stosunków etnicznych, to jednak w sumie podczas realizacji tej wymagającej najwyższego wysiłku pracy dominowała obiektywna nauka. Cieszymy się zatem, żeśmy otrzymali koherentne opracowanie kartograficzne stosunków fizyczno- i antropogeograficznych owego istotnego regionu Europy, który należy do trzech różnych państw ${ }^{29}$.

Polityczny ciężar atlasu wzmocniły dwa kolejne tłumaczenia. Najpierw, jeszcze w 1918 r., wyselekcjonowane mapy opatrzone angielskim komentarzem ukazały się w Stanach Zjednoczonych. Tym razem, inaczej niż w wersji z 1916 r., już wstęp informował czytelnika, że chodzi o naukowe uzasadnienie polskich roszczeń terytorialnych po zakończeniu wojny. Pozostałe zmiany dotyczyły map; na niektóre Romer naniósł linie mające uzmysłowić strategiczne znaczenie naturalnych (w jego mniemaniu) granic Polski ${ }^{30}$. Powstały $\mathrm{w}$ ten sposób Polski atlas kongresowy ukazał się w 1921 r. również w wersji francuskiej ${ }^{31}$. Także objaśnienia umieszczone bezpośrednio na mapach przeszły w nim drobne, ale istotne korekty. Uwage na tę zmianę zwrócił recenzent atlasu na łamach „Polskiego Przeglądu Kartograficznego”, Stanisław Pawłowski: „W objaśnieniu język niemiecki został zastąpiony przez angielski. Jest to zmiana najbardziej zasadnicza w całym wydawnictwie, która otworzy drogę Atlasowi w świecie amerykańsko-angielskim, gdzie Atlas był znany dotychczas tylko w kołach naukowych i dyplomatycznych"32.

${ }^{29}$ „Mag auch darin eine nationalpolitische Tendenz erblickt werden, von der sich auch die Nationalitätenkarte des Atlasses nicht ganz ferngehalten hat, so ist doch im allgemeinen bei der Durchführung der außerordentlich mühevollen Arbeit an diesem Atlas die wissenschaftliche Objektivität am Werke gewesen und wir freuen uns, für einen bedeutenden Teil Europas, der drei verschiedenen Staaten angehört, eine einheitliche kartographische Bearbeitung der physisch- und anthropogeographischen Verhältnisse erhalten zu haben", H. Hassinger, Neue Methoden der Darstellung der Volksdichte auf Karten, „Kartographische und schulgeographische Zeitschrift” 6, 1917, 3-4, s. 62-64.

${ }^{30}$ G.H. Herb, Under the Map of Germany. Nationalism and Propaganda 1918-1945, London-New York 1997, s. 21.

31 E. Romer, Polski atlas kongresowy, Lwów-Warszawa 1921; E. de Romer, Atlas de la Pologne (geographie et statistique), Léopol-Varsovie 1921.

32 S. Pawłowski, rec.: E. Romer, Geograficzno-statystyczny atlas Polski, wyd. 2, 1921, „Polski Przegląd Kartograficzny” 1, 1923-1924, 5, s. 207-208. 
We wstępie do tego wydania Romer informował o zaawansowanych pracach nad kolejną, w pełni angielską wersją atlasu, a także, nie bez satysfakcji, relacjonował wojenne losy swojego dzieła, wykorzystywanego zarówno przez francuskich, jak i amerykańskich ekspertów delegacji na paryską konferencję pokojową ${ }^{33}$.

Wojenne przypadki Jovana Cvijićia w wielu punktach przypominają losy Rudnic'kiego i Romera, z tym że jakby w jeszcze większej skali. Podobnie jak oni, Serb zmuszony był opuścić własny dom, a wkrótce potem kraj. W odróżnieniu od obu lwowiaków, których miasto uniknęło większych zniszczeń, mimo iż przechodziło w czasie wojny z rąk do rąk, na Cvijićia czekały ruiny i zgliszcza. Belgrad stał się miastem frontowym, wielokrotnie ostrzeliwanym przez austro-węgierską artylerię. W dodatku w czasie walk zniszczeniu uległa biblioteka uczonego (powojenna korespondencja z jego dawnym profesorem Penckiem dotyczy m.in. bezskutecznych poszukiwań Cvijićia książek i materiałów poprzez niemieckie władze wojskowe $\left.{ }^{34}\right)$. Jego drogi na obczyźnie także okazały się bardziej kręte i męczące. Jako największy serbski autorytet w kwestiach etnograficznych i kartograficznych, stał się cennym współpracownikiem rządu. Z ramienia i na prośbę premiera Nikoli Pašićia od 1915 r. przebywał w Londynie, Paryżu, w Szwajcarii, a także przez pewien czas w USA. Na jego zlecenie przygotowywał też pierwsze mapy przyszłej Jugosławii ${ }^{35}$. Rozchwytywali go również francuscy i brytyjscy specjaliści od Bałkanów; był niestrudzonym dostarczycielem studiów drukowanych w czasopismach poświęconych tym regionom ${ }^{36}$. Na dłużej zatrzymał się na Sorbonie, zaproszony tam przez samego Paula Vidala de la Blache. W roku akademickim 1917-1918 wykładał tam na swój ulubiony temat. Owocem tych wykładów była właśnie jedna z najbardziej wpływowych prac geograficznych okresu wojny, La Péninsule Balkanique. Géographie humaine, opublikowana ostatecznie w 1918 r.

Książka zarzuca czytelnika faktami i hipotezami z różnych dziedzin geografii i nauk pokrewnych. Wspólnym ich mianownikiem jest właściwie tylko to, że przemawiają na korzyść serbskiej dominacji na zachodnich Bałkanach, jednocześnie minimalizując wpływ Bułgarów. To ostatnie autor osiągnął za pomocą argumentów etnopsychologicznych

33 E. Romer, Atlas de la Pologne, Préface de la deuxième édition.

34 Arhiv Srpske Akademije Nauka i Umetnosti, Belgrad, fond Jovan Cvijić, sygn. 13484-953-48, List Pencka do Cvijićia, 6 VII 1920.

${ }^{35}$ L. Trgovčević, Nauka o granicama. Jovan Cvijić na konferenciji mira u Parizu 1919-1920, w: Zbornik Janka Pleterskega, red. O. Luther, J. Perovšek, Ljubljana 2003, s. 314.

36 A. Bernard, Le Monde Slave, première revue française consacrée aux pays slaves, „Revue des Études slaves” 74, 2002-2003, 2-3, s. 397-409. 
i rasowych. Bułgarzy, zdaniem Cvijićia, reprezentują kulturę odmienną od pozostałych narodów bałkańskich przede wszystkim ze względu na azjatyckie pozostałości. Jako mieszanka słowiańsko-azjatycka przynależą antropologicznie i kulturowo do cywilizacji turańskiej. Cechy rasowe traktował Cvijić dość niejednoznacznie. Z jednej strony odciął się od politycznego rasizmu (reprezentowanego przez Arthura de Gobineau i Georges'a Vacher de Lapouge), sugerując, że tego rodzaju argumentacji nie uważa za wartościową pomoc w badaniach antropogeograficznych. Z drugiej, tam, gdzie odpowiadało to jego tokowi myślenia (a więc w przypadku Bułgarów) przywoływał klasyfikacje antropologów rasowych takich jak William Z. Ripley. Różnica między argumentacją jednych i drugich wydaje się czysto formalna; serbski geograf odwołał się po prostu do rasistów z tytułami naukowymi, rytualnie odcinając się od tych, którzy w środowisku akademickim pozostawali ciałem obcym ${ }^{37}$. Cvijić nie rozpisywał się zresztą zanadto o charakterze bułgarskiej cywilizacji turańskiej, poprzestając na podkreśleniu autorytaryzmu i pasywności rzekomo konstytutywnych dla wszystkich ludów turańskich ${ }^{38}$. W jego dalszym rozumowaniu to właśnie stanowi punkt najważniejszy, inne narody bałkańskie są bowiem w tym ujęciu instynktownie demokratyczne i przedsiębiorcze ${ }^{39}$.

Z punktu widzenia oddziaływania najważniejszego dzieła serbskiego geografa największe znaczenie miały kwestie metodologiczne, to im bowiem zawdzięczał niemal powszechne uznanie. Słusznie, geograf łączył bowiem bardzo umiejętnie dwa zupełnie różne style myślenia. $\mathrm{Z}$ jednej strony ujmował Bałkany jako całość podlegającą wpływom historycznym, cywilizacyjnym i migracyjnym. Ukształtowały one kręgi cywilizacyjne: bizantyński, orientalny, środkowo- i zachodnioeuropejski oraz patriarchalny. Dla terytorialnego kształtu półwyspu największe znaczenie miała przepaść oddzielająca „orientalnych” Bułgarów od „patriarchalnych” Serbów, Czarnogórców i Albańczyków ${ }^{40}$. Z punktu widzenia francuskojęzycznych czytelników taka interpretacja bałkańskich realiów miała niebagatelne zalety. Potwierdzała okruchy wiedzy i powszechnie przyjęte stereotypy o Bałkanach jako regionie dokumentnie wymieszanych kultur i narodowości, dostarczając wiedzy o historycznych i demograficznych

${ }^{37}$ J. Cvijić, La Péninsule Balkanique. Géographie humaine, Paris 1918, s. 268-269.

38 Ibidem, s. 472-473, 479 n.

39 Ibidem, s. 520.

40 D. Mishkova, Regimes of „Balkan Historicity”. The Critical Turn and Regional Time in Studies of the Balkans before the First World War, w: "Regimes of Historicity” in Southeastern and Northern Europe, 1890-1945. Discourses of Identity and Temporality, red. D. Mishkova, B. Trencsényi, M. Jalava, Houndmills 2014, s. 21-42, tu s. 27-29. 
przyczynach tego stanu rzeczy. A jednocześnie pokazywała światełko w tunelu, przekonując, że na podstawie danych antropogeograficznych i etnopsychologicznych można w ten chaos wprowadzić pewien ład, oparty na wspólnocie cywilizacyjnej.

Z drugiej strony, tam gdzie rozważania serbskiego geografa schodziły na nieco niższy poziom, sprawnym narzędziem w jego ręku okazywało się instrumentarium niemieckiej antropogeografii, przejęte następnie przez geopolitykę. Jest tu więc mowa o przenikaniu i parciu naprzód albańskich elementów etnicznych, o bastionach i etnicznych zmaganiach, przyczółkach i frontach, tam zaś, gdzie niemieccy geografowie widzieli wyspy otoczone słowiańskim morzem, Cvijić dostrzegał serbskie oazy wśród albańskiej pustyni ${ }^{41}$.

Mocnym argumentem na rzecz pracy Cvijićia okazała się wreszcie jego metoda badawcza, zapożyczona u Pencka i stosowana z niezwykłą konsekwencją. W czasie, gdy wykładał na Sorbonie, miał już za sobą przeszło dwadzieścia lat intensywnych, nieraz kilkumiesięcznych wypraw po Bałkanach. Sam ten fakt podkreślał ${ }^{42}$, dostrzegali go także inni. Czeski geograf Jiří V. Daneš, towarzysz wielu podróży Serba, w tym właśnie widział jego wyjątkowość:

Studiowanie psychicznych właściwości zgodnie z zasadami Cvijićia, ustalonymi na podstawie długoletnich doświadczeń badawczych, udoskonaliło i pogłębiło dotychczasowe metody badań na tym dopiero od niedawna rozwijającym się polu antropologicznych i etnograficznych dociekań naukowych. Ani abstrakcje Wundta, ani metody socjologów francuskich nie były w stanie przeniknąć do samego jądra rzeczy. Były nazbyt suche, oddalone od przedmiotu swych badań. Cvijić zorientował się, że niemożliwym będzie dopracować się solidnych podstaw precyzyjnej pracy naukowej w tej dziedzinie bez głębokiego, intymnego przeniknięcia do duszy różnych fenomenów geograficznych i społecznych, tych cząstek narodu, o którym - jako całości, przyjdzie mu podać dane psychologiczne oparte na solidnych podstawach. Jego metoda jest zdecydowanie najbardziej wszechstronna i dociera najgłębiej do sedna sprawy ze wszystkich stosowanych dotąd na tym polu ${ }^{43}$.

${ }^{41}$ K. Clewing, E. Pezo, Jovan Cvijić als Historiker und Nationsbildner. Zu Ertrag und Grenzen seines anthropogeographischen Ansatzes zur Migrationsgeschichte, w: Beruf und Berufung. Geschichtswissenschaft und Nationsbildung in Ostmittel- und Südosteuropa im 19. und 20. Jahrhundert, red. M. Krzoska, H.-C. Maner, Münster 2005, s. 265-297, tu s. 287-288.

${ }^{42} \mathrm{~J}$. Cvijić, Balkansko poluostrvo i južnoslovenske zemlje. Osnove antropogeografije, Beograd 1966, s. 347.

43 „Vyšetřování psychických vlastnosti dle návodu Cvijićova, sestaveného na základě dlouholetých badatelských zkušeností, jest také zdokonalením a prohloubením dosavadních způsobů badání na tomto teprve nedávno se rozvíjejícím poli vědeckého 
Reakcje, z którymi spotkały się wojenne publikacje Rudnic'kiego, Romera i Cvijićia były oczywiście odbiciem politycznej sytuacji. Krytykę nader często motywował wzgląd na przyszłość europejskich granic. Tym bardziej uderzające wydaje się, że ze stanowiska fachowego częściej spotykały ich pochwały. Ta heterogeniczna natura recepcji ich dzieł (dostrzeżona już przez historyków geografii) ${ }^{44}$ uświadamia wyjątkowość środowiska, do którego wszyscy trzej się zaliczali. W porównaniu do licznych amatorów, kreślących mniej lub bardziej fantastyczne kontury swoich ojczyzn po wygranej wojnie, ci profesjonaliści mieli do zaoferowania coś więcej: spójne koncepcje, oparte na nowoczesnej nauce. Nie bez znaczenia okazało się ich wszechstronne przygotowanie fachowe. Dzięki niemu byli w stanie stworzyć dzieła o charakterze przekrojowym, ujmujące temat $z$ wielu różnych perspektyw. Oprócz propozycji map etnograficznych z równą swobodą poruszali się na polu geologii, geobotaniki (geografii roślin) czy geomorfologii. Ta wszechstronność okaże się przydatna w chwili, gdy skończy się wojna, a zaczną negocjacje pokojowe.

\section{Prace przygotowawcze}

Specyfika wojennych publikacji trzech geografów brała się nie tylko z ich nieprzeciętnego profesjonalizmu i wszechstronności. Wyjątkowy charakter miał również sam sposób pracy, opartej na indywidualnym wysiłku badacza. Patrząc na problem wojennego zaangażowania geografów w szerszej perspektywie, należałoby uznać, że normą była raczej praca zbiorowa. Większe grupy ekspertów działały w ramach towarzystw geograficznych bądź jako ad hoc zwoływane zespoły, pracujące na bieżące potrzeby armii. W 1917 r. rządy walczących mocarstw zainteresowały się tematem przyszłych granic na poważnie. Najpierw we Francji powołany został zespół ekspertów, znany jako Comité d'études. Przewodniczył mu

výzkumu, na poli anthropogeografickém a národopisném. Abstrakce Wundtova ani metody francouzských sociologů nebyly schopny proniknouti k samému jádru věci. Byly př́liš suché, předmětu svého šetření vzdálené a Cvijić poznal, že není možno proniknouti $\mathrm{k}$ bezpečným základům pro přesnou práci vědeckou v tomto oboru bez hlubokého intimního proniknouti do duše různých geografických a společenských útvarů a složek národa, o jechož psychologíi jako celku třeba podati data vědecky založená. Jeho metoda jest zajisté nejvšestrannější a jde nejhlouběji k jádru věci ze všech na tomto poli dosud užívaných", J.V. Daneš, Jovan Cvijić. K jeho šedesátým narozeninám, Praha 1925, s. 22.

${ }^{44}$ A. Osowska, D. Przybytek, Thematic Maps in Eugeniusz Romer's Geographical and Statistical Atlas of Poland from 1916 - The Historical and Methodological Perspective (on the 100year Anniversary of the Publication), „Polish Cartographical Review” 48, 2016, 2, s. 77-86. 
historyk Ernest Lavisse, a wśród przeszło trzydziestu członków znaleźli się także geografowie specjalizujący się w problemach Europy Środkowo-Wschodniej i Bałkanów: Emmanuel de Martonne i Jean Brunhes. Wiceprezydentem komitetu został Vidal de la Blache ${ }^{45}$. Z czasem znaczenie specjalistów od geografii w komisji rosło, dokooptowani później członkowie najczęściej reprezentowali właśnie tę dziedzinę nauki ${ }^{46}$. Bardziej imponująco prezentował się amerykański odpowiednik tego organu, utworzona we wrześniu 1917 r. pod auspicjami American Geographical Society tzw. Inquiry. Organizacją nowej instytucji zajął się na prośbę prezydenta Thomasa Woodrowa Wilsona jego doradca, płk Edward M. House. Ciało to liczyło ponad pół setki ekspertów, w tym kilkunastu geografów ${ }^{47}$. $\mathrm{Na}$ ich potrzeby przystosowano odpowiedni budynek i uruchomiono wszystkie dostępne środki, by dostarczyć im maksimum informacji ${ }^{48}$.

Podobne struktury, choć nie tak rozbudowane i scentralizowane jak francuska i amerykańska, powstały także w innych państwach: Wielkiej Brytanii i Włoszech. Mocarstwa nie były jednak odosobnione w zapobiegliwych przygotowaniach do przyszłego pokoju na kontynencie. W tym samym czasie, kiedy Wilson powoływał do życia Inquiry, posiadająca dużo skromniejsze środki (nie wspominając o pozycji międzynarodowej) Tymczasowa Rada Stanu Królestwa Polskiego, zależnego od Niemiec, dysponującego jednak własnymi agendami rządowymi, podjęła decyzję o utworzeniu Biura Prac Przygotowawczych ${ }^{49}$. Jego struktura przypominała podział zadań przyjęty w Comité d'études oraz Inquiry: zaproszeni specjaliści mieli się zajmować kwestiami prawnymi, terytorialnymi, gospodarczymi, komunikacyjnymi i odszkodowaniami wojennymi. Burzliwy przebieg kilkunastu ostatnich miesięcy niemieckiej okupacji utrudnił dłuższe działanie tego tworu, ale w listopadzie $1918 \mathrm{r}$. rozpoczął on drugie życie, tym razem w formie Biura Prac Kongresowych (BPK) o podobnym profilu, podzielonego na wydziały prawny, historyczny, statystyczny i ekonomiczny. Nowa instytucja była silniejsza liczebnie, co znalazło oddźwięk w liczbie specjalistycznych opracowań przygotowanych na okoliczność negocjacji pokojowych. Polskie Biuro

${ }^{45}$ G. Palsky, op. cit., s. 111-119.

${ }^{46}$ E. Boulineau, Un géographe traceur de frontières. Emmanuel de Martonne et la Roumanie, „L'Espace géographique” 2001, 4, s. 358-369, tu s. 359.

47 The American Geographical Society's Contribution to the Peace Conference, "The Geographical Review" 7, 1919, 1, s. 1-10.

48 Ibidem, s. 4.

49 B. Pasierb, Polskie prace przygotowawcze do Traktatu Pokojowego z Niemcami 19161948. Instytucje - ludzie - problemy, Wrocław 1996 (Acta Universitatis Wratislaviensis No. 1803, Politologia 18), s. 21-130. 
Prac Przygotowawczych bardzo zdecydowanie wyprzedziło regionalną konkurencję. Mobilizacja krajowych ekspertów w innych krajach Europy Środkowo-Wschodniej i Bałkanów nastąpiła na ogół dopiero wówczas, gdy walki na froncie zachodnim ustały, a decyzja o terminie i miejscu konferencji pokojowej została ogłoszona.

Oczywiście pomysł, by politykę w czasie wojny oprzeć na specjalistycznej wiedzy, nie zrodził się dopiero w obliczu zapowiedzi kongresu pokojowego. W czasie, gdy polskie Biuro rozpoczęło efektywną działalność, istniały już pierwsze agendy, mające częściowo podobne zadania. Jednak ciała te funkcjonowały przede wszystkim za granicą, a ich dostęp do najlepszych ekspertów często był utrudniony, ograniczały się więc do działań propagandowych, niepodpartych szczegółową wiedzą o kraju i ludziach. W dodatku nie brakło wśród nich i takich, które najwyraźniej w wojnie światowej postawiły na złego konia. Szczególnie wyraźnie widać to w przypadku Ukrainy. Działacze narodowi w Wiedniu i w Berlinie mogli wprawdzie bez ograniczeń korzystać z ekspertów, także tych znajdujących się na emigracji, na przykład Rudnic'kiego. Problem w tym, że ich wysiłki propagandowe, nakierowane dotąd prawie wyłącznie na mocarstwa centralne, z trudem poddawały się reorientacji wymuszonej przez nieoczekiwany obrót wojennych wypadków. Wielokrotne deklaracje niezachwianej ufności w Niemcy i Austro-Węgry psuły wizerunek Ukraińców w oczach zwycięskich mocarstw i ułatwiały zadanie przeciwnikom, oskarżającym ich o proniemieckość. $Z$ kolei zwrot w polityce światowej zastał Ukrainę w stanie chaosu, utrudniając skuteczne prowadzenie polityki zagranicznej. Ententa miała niestety dobrą pamięć. W styczniu 1919 r. z Kijowa wyruszyło około 60 członków delegacji ukraińskiej na paryskie rokowania, na miejsce dotarło jednak zaledwie kilkunastu. Pozostałym Francuzi odmówili wiz, tłumacząc to ich zaangażowaniem w negocjacje pokojowe z Niemcami w Brześciu ${ }^{50}$. Z oczywistych przyczyn podobne ograniczenia dotyczyły sojuszników mocarstw centralnych, na przykład Bułgarii. W zbliżonej sytuacji znalazły się również zagraniczne ekspozytury polskiego Naczelnego Komitetu Narodowego. Nawet jeśli niektórzy wpływowi eksperci z państw Ententy, jak na przykład Lewis Namier, czołowy brytyjski specjalista od Europy Środkowo-Wschodniej, popierali polską lewicę, jej proaustriacka postawa była skazą trudną do usunięcia ${ }^{51}$.

50 P. Żurawski vel Grajewski, Sprawa ukraińska na konferencji pokojowej w Paryżu w roku 1919, Warszawa 1995, s. 19.

${ }^{51}$ A. Ng, A Portrait of Sir Lewis Namier as a Young Socialist, ,Journal of Contemporary History" 40, 2005, 4, s. 621-636. 
Znacznie lepiej przedstawiała się sprawa jugosłowiańska. Po podpisaniu porozumienia pomiędzy Komitetem Jugosłowiańskim, reprezentującym Słowian Południowych z monarchii habsburskiej, a rządem Serbii, kluczowym ekspertem obu tych obozów został Jovan Cvijić, mąż stanu i naukowiec w jednej osobie. Dzięki kontaktom wypracowanym w czasie wojny jego pozycja zwłaszcza wśród francuskich i amerykańskich ekspertów była bardzo mocna ${ }^{52}$. Ten sam czynnik poprawiał także stanowisko Czechów i Słowaków, chociaż we znaki dawał im się brak podobnej osobowości, która łączyłaby dwa światy: działaczy politycznych i specjalistów od ustalania granic. Rolę ekspercką częściowo wykonywali za Czechosłowaków inni. Ważnym narzędziem ich propagandy stało się założone w 1916 r. wpływowe czasopismo „The New Europe”, redagowane przez szkockiego historyka Roberta Seton-Watsona i współfinansowane przez Tomáša G. Masaryka. Ideą przewodnią pisma była walka o wyzwolenie narodowości uciskanych przez Habsburgów. Oczywiście nie było to jedyne narzędzie w zmaganiach o uwagę i sympatię Zachodu. Być może dla pozyskania brytyjskiej opinii publicznej większe znaczenie miały prostsze działania propagandowe prowadzone przez czechosłowacki ośrodek otwarty na Piccadilly Circus a następnie czeskie biuro prasowe, także w Londynie, nie były to jednak instytucje eksperckie ${ }^{53}$.

Do tej samej kategorii należy zaliczyć działania kierowanego przez Romana Dmowskiego Komitetu Narodowego Polskiego (KNP). Podobnie jak akcja zagraniczna Czechosłowaków i Jugosłowian, jego działalność w czasie wojny miała wprawdzie w dalekiej perspektywie uzyskanie niepodległości (przynajmniej od momentu upadku caratu), na bieżąco skupiała się jednak z konieczności na celach krótkoterminowych: uzyskaniu statusu przedstawicielstwa kraju sprzymierzonego, zgody na formowanie własnych sił zbrojnych, propagandzie w prasie i wydawnictwach broszurowych czy też walce o prawo do używania poczty kurierskiej i linii telegraficznej ${ }^{54}$. Zawsze pewny siebie Dmowski starał się słabość swojego otoczenia przekuć w siłę, konsekwentnie deprecjonując rolę ekspertów. W jego wyobrażeniu politykę powinni uprawiać politycy. Dał temu wyraz choćby w londyńskim memorandum z lipca 1917 r.:

Jest rzeczą całkiem zrozumiałą, że wojna obecna, największa w dziejach świata, wywołała obfitą literaturę poświęconą przebudowie Europy, kreślącą

52 N. Ginsburger, Réseaux académiques.

${ }^{53}$ H. Hanak, Great Britain and Austria-Hungary during the First World War. A Study in the Formation of Public Opinion, London 1962, s. 120.

${ }^{54}$ J. Sibora, Dyplomacja polska w I wojnie światowej, Warszawa 2013, s. 402. 
granice, które nigdy nie istniały, rozwalającą całe państwa i budującą nowe. Również zrozumiałe jest, że wytrawni mężowie stanu patrzą na te próby przerobienia karty Europy podejrzliwie, uważając je za roboty nieodpowiedzialne, wykonane przy biurku przez ludzi, którzy się zajmowali w życiu jeno pisaniem i którzy o warunkach istnienia państw nie mają pojęcia. Doświadczenie uczy mężów stanu konserwatyzmu, nie dowierzają oni temu, czego nie znają... ${ }^{55}$

Takie rozumowanie nie było już w drugiej połowie 1917 r. normą wśród mężów stanu. Zresztą działania, które podejmował KNP, często przeczyły słowom Dmowskiego. Czym innym, jak nie próbą zbudowania sobie eksperckiego zaplecza, była organizacja Wydziału Studiów, Wydawnictw i Propagandy KNP w październiku 1918 r.? ${ }^{56}$ Tak jak działania innych reprezentacji narodowych i ta inicjatywa wskazuje, że dość powszechnie odczuwano brak wystarczającego wsparcia merytorycznego. Problemem było zgromadzenie ludzi i środków potrzebnych do tego celu. Działania Francuzów, Brytyjczyków i Amerykanów pokazywały, że rzeczywistość była zupełnie inna niż pisał Dmowski. Bez ścisłej współpracy $z$ akademickimi elitami tam, gdzie się znajdowały, a więc nie na emigracji, lecz w kraju, poważnej dyplomacji już nie dało się uprawiać.

\section{Paryż}

W Polityce polskiej i odbudowaniu państwa, tym niezwykłym raporcie z walki o niepodległą Polskę i zarazem bezwstydnym peanie na własną cześć, o ekspertach delegacji paryskiej Dmowski wspomina oszczędnie i dość krytycznie:

Nigdy nie mogłem zrozumieć, co sobie myśleli ludzie zamawiający przed konferencją u kogo się dało referaty na wszelkie możliwe tematy polskie, nie mające często żadnego związku ze sprawą naszą na konferencji. Czy spodziewali się, że Lloyd George to będzie czytał?... Bo nam to było niepotrzebne i nie mieliśmy na to czasu. Jednym z najważniejszych warunków skutecznej pracy jest nie robić rzeczy niepotrzebnych, a dobrego gospodarstwa - nie wydawać pieniędzy na rzeczy zbyteczne ${ }^{57}$.

${ }^{55}$ R. Dmowski, Polityka polska i odbudowanie państwa, t. 2, oprac. T. Wituch, Warszawa 1988 , s. 225.

${ }^{56}$ B. Pasierb, Polskie prace przygotowawcze, s. 96-98.

57 R. Dmowski, op. cit., s. 132. 
Skąd jednak w ogóle wzięli się polscy eksperci w Paryżu? Oczywiście na prośbę Dmowskiego i jego współpracowników. Kiedy podano do wiadomości publicznej, że 18 stycznia 1919 r. konferencja pokojowa zacznie obrady, z KNP do Warszawy zaczęto wysyłać najpierw listy, a następnie telegramy ponaglające do przysłania materiałów i kompetentnych ludzi: „Wobec rozpoczęcia prac Konferencji Pokojowej - pisano w jednym z nich - prosimy o niezwłoczne wydelegowanie ekspertów wraz z całym zebranym materiałem i źródłami z archiwów dawnych okupantów"58.

Czas naglił, więc spieszyli się nie tylko Polacy. W Pradze grupa ekspertów do spraw terytorialnych zebrała się po raz pierwszy w listopadzie, od razu przystępując do pracy. Podstawową trudność stanowił brak codziennego kontaktu z czechosłowackim przedstawicielstwem w Paryżu:

Wadą wszystkich naszych ówczesnych prac w komisji terytorialnej była $\mathrm{z}$ jednej strony niewystarczająca wiedza o zagranicznych możliwościach, a z drugiej przesadzone postulaty niektórych maksymalistów. Komisja nie miała żadnych precyzyjnych dyrektyw i wciąż jeszcze żadnego kontaktu z Paryżem, mało tego, w dodatku nie wiadomo z jakiego źródła chyba za sprawą nieostrożnej wypowiedzi któregoś z członków genewskiej delegacji - pojawiła się pogłoska, kolportowana z komisji do komisji jako potwierdzona prawda, że Ententa da nam każde terytorium, jakiego sobie tylko zażyczymy ${ }^{59}$.

Z pewnym opóźnieniem ta sama sekwencja wydarzeń powtórzyła się w Niemczech. Minister spraw zagranicznych Ulrich von Brockdorff-Rantzau wybrał się do Paryża pod koniec kwietnia 1919 r. nie dość, że z bardzo skąpym zapleczem ekspertów, to jeszcze nawet bez map. Niemal natychmiast po przybyciu na miejsce zrozumiał, że popełnił błąd. Trzeba było błyskawicznie dosyłać z Berlina mapy terenów spornych, a że Niemcy nie były przygotowane na jakiekolwiek straty terytorialne na wschodzie, delegaci musieli się w tym wypadku posługiwać zwykłymi atlasami, dostępnymi w tamtym czasie na rynku ${ }^{60}$. Znacznie lepiej przygotowali

58 Cyt. za: B. Pasierb, Polskie prace przygotowawcze, s. 41-42.

59 „Vadou všech našich tehdějších prací v územní komisí była jednak nedostatečná informovanost o zahraničních možnostech, jednak přemrštěné požadavky některých maximalistů. Komise neměla žadné přesné direktivy a žádného styku tehdy ještě s Paříží, nejen to, nýbrž naznámo z jakého zdroje - snad neopatrným vyjádřením některého člena ženevské delegace - vznikla pověst, kolportovaná z komise do komise jako zaručená prawda, že dohoda nám dá do státu všechno území, o které jen požádáme", J. Kapras, O českém státě za války a po válce (soubor článků), Praha 1925, s. 12.

${ }^{60}$ U. Jureit, Das Ordnen von Räumen. Territorium und Lebensraum im 19. Und 20. Jahrhundert, Hamburg 2012, s. 195. 
się do negocjacji Węgrzy, wyposażeni w mapy, statystyki i opracowania historyczne, niestety w Paryżu nikt nie chciał z nimi rozmawiać61.

Zachowana dokumentacja polskiego BPK pokazuje, jak wszechstronne prace podejmowano ${ }^{62}$. Jest to zarazem model typowy dla większości delegacji. Ekspertyzy przygotowywano najczęściej w języku polskim z intencją dostarczenia informacji polskiemu przedstawicielstwu podczas negocjacji pokojowych. Te poświęcone kwestiom szczególnie istotnymi/lub drażliwym przygotowywano w językach kongresowych. Franciszek Bujak, wybitny historyk, opracował w języku polskim materiały o przyszłości politycznej Litwy, o mniejszości polskiej w Niemczech i o średniowiecznej historii Bałtyku, po angielsku zaś informację o żegludze na rzekach Prus Wschodnich oraz na Odrze i jej dopływach ${ }^{63}$, a także o kwestii żydowskiej w Polsce (zapewniał w niej, że antysemityzm „nie jest ruchem agresywnym, manifestującym się w konsekwentnym działaniu, lecz raczej reakcją psychiczną na szkody poniesione przez naród polski za ich [Żydów] sprawą") ${ }^{64}$. Inne opracowania dotyczyły aktualnej sytuacji politycznej w krajach ościennych, problemu uchodźczego, a nawet „rozprzestrzenienia się antropologicznego typu ukraińskiego wśród ludności między Wisłą, Dnieprem i Horyniem" ${ }^{65}$.

Gros opracowań koncentrowało się jednak na kwestii dużo mniej oryginalnej: przebiegu przyszłych granic państwa. W zbiorze tym znajdują się zarówno opracowania autorskie, jak i krytyczne omówienia broszur publikowanych przez inne delegacje. Jedną z pierwszych wziętych „na warsztat" okazała się zresztą publikacja Jana Kaprasa, autora cytowanego powyżej wspomnienia o chaotycznych początkach czechosłowackich prac kongresowych. W wydanej wiosną 1918 r. pracy 0 české Těšínsko przekonywał, że powinnością narodową jest trwać na stanowisku przynależności śląska Cieszyńskiego do przyszłego państwa z powodów historycznych, narodowościowych i geograficznych, ponieważ Śląsk Cieszyński tworzy nierozdzielną część czeskiego państwa ${ }^{66}$. Polski referent nie bez racji oceniał, że: „Rzecz jest tak ułożona, fakta tak dobrane, światła i cienie tak rozmieszczone, że odnosi się wrażenie, iż broszura sama

${ }^{61}$ C.A. Macartney, Hungary and Her Successors. The Treaty of Trianon and Its Consequences 1919-1937, Oxford 1937, s. 481-482.

${ }^{62} \mathrm{~W}$ tym fragmencie tekstu omawiam dokumenty znajdujące się w AAN, Biuro Prac Kongresowych (dalej: BPK).

${ }^{63}$ Ibidem, sygn. 58, k. 1-15.

${ }^{64}$ F. Bujak, The Jewish Question in Poland, w: Ekspertyzy i materiaty delegacji polskiej na konferencję wersalska 1919 roku, oprac. M. Przyłuska-Brzostek, Warszawa 2009, s. 381-425, tu s. 407.

${ }^{65}$ AAN, BPK, sygn. 255 (Stanisław Srokowski), k. 1-2.

${ }^{66}$ J. Kapras, op. cit., s. 71-73, tu s. 73. 
ma służyć na użytek podręczny dla rokowań dyplomatycznych"67. Jeśli weźmiemy pod uwagę, że polskie opracowania spotykały się z podobnie żywym odzewem, łatwiej przyjdzie nam uświadomić sobie, jak wielki był wysiłek intelektualny i finansowy zwłaszcza tych państw, które dopiero powstawały. Niektóre „fronty” polemicznych bojów wymagały naprawdę znacznych nakładów pracy i farby drukarskiej. Do najbardziej zaciętych należał propagandowy konflikt polsko-zachodnioukraiński ${ }^{68}$. Im aktywniejsi byli eksperci jednej strony, tym więcej pracy wymagała polemika z nimi przez ekspertów strony przeciwnej.

Publikacje okołokonferencyjne można pod względem formalnym podzielić na trzy kategorie. Pierwszą stanowiły oficjalne wydawnictwa przedstawicielstw dyplomatycznych i innych organizacji albo biorących udział w konferencji, albo aktywnie działających na jej marginesie. W przypadku polskim jako wydawca figurowała Commission polonaise des travaux préparatoires au Congrès de la Paix, w publikacjach anglojezzycznych Polish Commission of Work Preparatory to the Conference of Peace, ale także na przykład Délégation polonaise à la Conférence de la Paix, Commission Scientifique albo Bureau polonaise de publications politiques. Węgrzy, chociaż jako pokonani nie mieli prawa do bezpośredniego uczestnictwa $\mathrm{w}$ obradach, zasypywali konferencję publikacjami wydawanymi przez Hungarian Territorial Integrity League. Zapewne lepszą taktyką był druk w uznanych międzynarodowych wydawnictwach. Na to jednak mogli sobie pozwolić tylko niektórzy eksperci z naszej części Europy, przede wszystkim Jovan Cvijić, wydający swoje prace kongresowe w prestiżowym wydawnictwie naukowym Armand Colin. Wszyscy pozostali chwytali się mniej ambitnych środków. Duża część broszur powstałych przy okazji konferencji w ogóle nie podawała wydawcy, część (na przykład ukraińskich) drukowano w wydawnictwach własnych tytułów prasowych. W polityce wydawniczej odbijała się także historia najnowsza. Ci, którzy jeszcze do niedawna produkowali propagandę głównie na rynek niemieckojęzyczny, publikacje francuskie wydawali na ogół w wydawnictwach szwajcarskich. Argumenty litewskie docierały do Paryża za pośrednictwem wydawnictwa Atar.

Liczba specjalistycznych publikacji przygotowywanych z myślą o konferencji pokojowej była ogromna. Dla francuskich i szwajcarskich wydawnictw stanowiły dobrą okazję do zarobku, dla delegatów - pasmo

${ }^{67}$ AAN, BPK, sygn. 81 (Fr. Duda), k. 2.

${ }^{68}$ G. de Castelbajac, S. de Gasquet, G.-H. Soutou, Recherches sur la France et le problème des nationalités pendant la Première Guerre Mondiale (Pologne, Ukraine, Lithuanie), Paris 1995, s. 174-177 i 198-206. 
kłopotów z poprawianiem błędów językowych i omyłek drukarskich, organizacją, dystrybucją i finansami. Władysław Konopczyński, wybitny historyk, w Paryżu odpowiedzialny za wydawnictwa delegacji polskiej, w swoich dziennikach niejednokrotnie dawał wyraz zmęczeniu tym niewdzięcznym zadaniem. Denerwowało go bezrefleksyjne wykorzystywanie tych samych broszur dla uzasadnienia różnych, czasem sprzecznych dążeń polskich negocjatorów ${ }^{69}$. Angielscy korektorzy, zatrudniani przez delegację, bynajmniej nie zawsze rozumieli teksty, które poprawiali. W kwietniu 1919 r. Konopczyński notował: „Drukarze spisują się fatalnie: Fournier nie dotrzymuje terminów, a Courmont robi nieprzewidziane błędy"70. Egzekwowanie umów było o tyle trudne, że często poprzestawano na zleceniach ustnych, regulowanych w miarę napływu gotówki, której jak zwykle brakowało. W maju drukarnia Courmonta popełniła błąd nieco poważniejszy, bo znajdujący się na okładce jednej z polskich broszur. Konopczyński liczył, że składając reklamację uzyska zniżkę i nie krył rozczarowania, kiedy zamiast tego drukarnia przygotowała poprawioną wersję okładek ${ }^{71}$.

Opracowania publikowane i te pozostające w rękopisie do dyspozycji delegacji miały nie tylko przekonywać obcych. Niekiedy mogły spełniać jeszcze jedną funkcję, być może ważniejszą. Część z nich stała się podstawą do przygotowania memorandów skierowanych do tak zwanej Rady Dziesięciu (składającej się z prezydentów i premierów delegacji zwycięskich mocarstw: USA, Wielkiej Brytanii, Francji, Włoch i Japonii). Tu jednak rzeczywistość nie sprzyjała spokojnemu wczytywaniu się w racje młodych państw. Rada Dziesięciu w praktyce szybko stała się Radą Pięciu z jednym przedstawicielem każdego z mocarstw. Ignorowanie Japonii przez państwa zachodnie przyniosło wkrótce efekt w postaci uformowania Rady Czterech, a że z podobnym lekceważeniem przywódcy mocarstw traktowali aspiracje Włoch, skończyło się na Radzie Trzech. Liczyć, że tak wąskie grono zawodowych polityków zapozna się ze zrozumieniem choćby z bardzo oszczędną kolekcją memorandów, oznaczałoby brak realizmu ${ }^{72}$. Zresztą niemała część toczonych przez nich rozmów utrzymywana była w tajemnicy przed delegatami innych państw, co przyczyniło się do pogorszenia atmosfery paryskich rokowań ${ }^{73}$.

69 W. Konopczyński, Dziennik 1918-1921, cz. 1, oprac. P. Biliński, P. Plichta, Warszawa-Kraków 2016, s. 353.

70 Ibidem, s. 362.

${ }^{71}$ Ibidem, s. 402.

72 R. Petráš, Organisational Aspects of the Paris Peace Conference (1919-1920), „Central European Papers" 3, 2015, 2, s. 34-44, tu s. 37.

${ }^{73}$ R. Lansing, Die Versailler Friedens-Verhandlungen. Persönliche Erinnerungen, Berlin 1921, s. 177 n. 
Memoranda z reguły dotyczyły najbardziej palących kwestii terytorialnych, dostarczając przy okazji podstawowych wiadomości o położeniu geograficznym i historii regionu. Widać to wyraźnie na przykładzie dziewięciu pism przygotowanych na potrzeby konferencji przez delegację czechosłowacką. Ułożone w kolejności chronologicznej pokazują gradację spraw od najpilniejszych do drugorzędnych. Pierwsze informowało w ogólności kim są i jaką przeszłość mają za sobą Czechosłowacy. Podstawowe wiadomości podano w nim w towarzystwie haseł panslawistycznych, antyniemieckich i demokratycznych ${ }^{74}$. Kolejne informowało o terytorialnych postulatach Czechosłowaków, opartych na kombinacji argumentów historycznych i etnicznych. Obok polemiki z zafałszowaną austriacką i węgierską statystyką narodowościową, dokument formułował zaskakującą tezę o geograficznej jedności projektowanego państwa, dosypując garść argumentów geopolitycznych, dowodzących jego wagi dla układu sił w Europie: „Niemcy i Węgrzy pojęli, że aby skutecznie prowadzić ten bój ze Słowianami, trzeba przede wszystkim oddzielić Słowian północnych od południowych" - przekonywali autorzy, legitymizując w ten sposób wyśrubowane postulaty terytorialne pod adresem Węgier ${ }^{75}$. Trzecie z kolei memorandum podejmowało palący problem Niemców na ziemiach czeskich, przekonując, że po pierwsze, nie ma ich tam aż tak dużo, jak twierdziła austriacka statystyka, a poza tym historyczne granice winny być i tak z przyczyn strategicznych nienaruszalne. o kolejności najważniejszych problemów terytorialnych, przed którymi stała młoda republika, świadczą tematy sześciu przygotowanych w krótkim odstępie czasu memorandów: Śląsk Cieszyński, Słowacja, Ruś Podkarpacka, Łużyce, reklamowany przez ČsR fragment Górnego Śląska i wreszcie skrawek Kotliny Kłodzkiej. Memorandom towarzyszyły czarno-białe mapki. Najciekawsza i najsolidniej wykonana (notabene przez Kaprasa) przedstawiała $\mathrm{w}$ ujęciu historycznym postępy germanizacji ziem czeskich. Jej rola polegała na podkreśleniu trwałości granic historycznych ziem korony św. Wacława (będących w oczach Kaprasa również granicami naturalnymi) w zestawieniu z ulotnym, bo późniejszym procesem germanizacji, który można wszak będzie odwrócić. Zestawienie dwóch porządków: historycznego kształtu narodowych granic i ich późniejszej

${ }^{74}$ Les Tchécoslovaques. Leur histoire et civilisation - Leur lutte et leur travail - Leur rôle dans le monde, w: Die tschechoslowakischen Denkschriften für die Friedenskonferenz von Paris 1919/1920, oprac. H. Raschhofer, Berlin 1938 (2 wyd.), s. 2-33. Kolejne memoranda cytuję za tym samym zbiorem.

75 „Deutsche und Magyaren haben begriffen, daß man, um diesen Kampf gegen die Slawen mit Erfolg führen zu können, vor allem die Nordslawen von den Südslawen trennen mußte", ibidem, s. 61. 
„dewiacji” za sprawą obcego osadnictwa pozwalało delegatom występować w charakterze obrońców „naturalnego” porządku.

Rola większości ekspertów ograniczała się do pracy, nieraz „na wczoraj", nad materiałami do takich memorandów oraz do wspomnianych wcześniej publikacji, gdzie nagromadzone informacje mogły znaleźć ujście szersze niż w skrótowych notach kierowanych do mocarstw. Zupełnie wyjątkowo zdarzało się, że zawodowi politycy dopuszczali specjalistów do bezpośredniego udziału w negocjacjach. Nieco więcej do powiedzenia mieli geografowie uczestniczący w pracach podkomisji terytorialnych. Takie podkomisje tworzono dla wstępnego opracowania propozycji rozwiązania szczególnie zagmatwanych kwestii granicznych. Tu, jak zauważał redaktor brytyjskiego „Geographical Journal”, niektóre mniejsze państwa dobrze skorzystały na obecności geografów w składach swoich delegacji, czego najlepszym przykładem mogli być Jugosłowianie i Polacy ${ }^{76}$.

Czy ostrożność w dopuszczaniu geografów do głosu była usprawiedliwiona? Obserwacje poczynione przez brytyjskie czasopismo wydają się temu raczej przeczyć. Zwłaszcza Cvijić miał w Paryżu kilka okazji, by wykazać się zarówno kompetencjami naukowymi, jak i kunsztem dyplomatycznym. Pierwsza z nich wymagała podjęcia polemiki z długoletnim przyjacielem Serba, Emmanuelem de Martonne. Kwestia sporna dotyczyła podziału Banatu między Królestwo Serbów, Chorwatów i Słoweńców i Rumunię. Cvijić nie chciał się zgodzić na lekko zmodyfikowaną propozycję przedstawioną przez premiera Iona Brătianu. W niezręcznej sytuacji (spór toczył się pomiędzy sojusznikami) odwołano się do Martonne'a i to jego wariant, stosunkowo korzystniejszy dla Rumunii, przyjęto jako podstawę delimitacji ${ }^{77}$. Ciekawy przebieg miała dyskusja obu geografów na temat podziału Kotliny Klagenfurckiej. Dyskusję ponownie zdominowali Cvijić i Martonne. Pierwszy opowiadał się za podziałem Kotliny według swoiście rozumianych zasad etnograficznych. Swoistość jego interpretacji polegała na uhistorycznieniu argumentacji. Cvijić stwierdził, że Karyntia stała się polem germanizacji, zamazującej „pierwotny” i „naturalny” charakter etniczny regionu. Stosując taktykę podobną jak delegacja czechosłowacka, głosząca tezę o odwracalności procesów historycznych, przedstawił mapę postępów języka niemieckiego od 1851 r. Wszystko to, jak dowodził, można wymazać dzięki połączeniu miejscowych Słowian z ich pobratymcami z Bałkanów. I właśnie ten element argumentacji Cvijićia dał asumpt to dyskusji, która na jakiś

76 Geography at the Congress of Paris, 1919, „The Geographical Journal” 55, 1920, 4, s. 309-312, tu s. 311.

77 E. Boulineau, Un géographe traceur de frontières, s. 358-369. 
czas wyniosła Karyntię z pozycji przedmiotu sporu dyplomatycznego na wyżyny teoretycznej debaty uczonych.

Zaproponowany przez Cvijićia obraz przeszłości prowincji był dynamiczny nie tylko ze względu na postępy germanizacji. W ogóle, jak dowodził, Karyntia jako część Półwyspu Bałkańskiego poddana jest ciągłym migracjom, przede wszystkim z południa. Przybywający stamtąd Serbo-Chorwaci doprowadzili z czasem do serbizacji ludności miejscowej. Zgodnie ze swoim zwyczajem, Cvijić nie twierdził, że proces ten miał charakter biologiczny. Południowych Słowian uważał za wspólnotę typu psychicznego. Jego argumenty szczegółowe były logicznym rozwinięciem przyjętych założeń. Opowiadał się na przykład za takim wyznaczeniem granicy, by odebrać Austrii połączenia kolejowe z prowincją. W ten sposób, jak rozumował, jedno z najskuteczniejszych narzędzi germanizacji zostałoby unieszkodliwione.

Poproszony o radę Martonne przeciwstawił argumentacji serbskiego przyjaciela wizję Kotliny Klagenfurckiej jako regionu, którego jedność należy zachować. Wychodząc z tego stanowiska, opowiadał się przeciw jakiemukolwiek podziałowi. Nie była to wcale argumentacja sprzeczna z interesami Królestwa SHS. Jedność tę można było zachować równie dobrze w jego ramach i właśnie ku takiej opcji skłaniał się Martonne. Doszło tu więc do dość paradoksalnej sytuacji, w której postulaty terytorialne Cvijićia zostały przez eksperta mocarstw uznane za zbyt skromne ${ }^{78}$.

Choć z punktu widzenia dyplomatów być może zaskakujący, spór pomiędzy Cvijićiem i Martonne'em był osadzony w logice nauki. Obydwaj mieli ambicje tworzenia antropogeograficznych modeli obejmujących całe regiony. W Karyntii, jak dowodzi Emmanuelle Boulineau, wizja wielkich Bałkanów starła się z wywodzącą się od Vidala de la Blache'a koncepcją jedności organicznych regionów geograficznych ${ }^{79}$. Proste dążenie do ekspansji ustąpiło zatem przed argumentami wywiedzionymi z zupełnie innej sfery.

Praktyczny wynik negocjacji nie usatysfakcjonował ani Martonne'a, ani Cvijićia. Przekonani przez Francuza przedstawiciele mocarstw zdecydowali się ostatecznie na przeprowadzenie w Karyntii plebiscytu, który dał wynik pomyślny dla Austrii. Jedność regionu została wprawdzie zachowana, ale nie w tym organizmie państwowym, w którym najchętniej widziałby go Martonne.

${ }^{78}$ E. Boulineau, Les géographes et les frontières austro-slovènes des Alpes orientales en 1919-1920, „Revue de Géographie Alpine” 2001, 4, s. 173-184. O innych przejawach samoograniczenia postulatów terytorialnych w wystąpieniach Cvijićia pisze Ljubinka Trgovčević, op. cit., s. 313-318.

79 E. Boulineau, Les géographes et les frontières, s. 180-191. 
Francuski geograf jeszcze kilkakrotnie zaznaczył swoją obecność na konferencji pokojowej. Przede wszystkim zajmowała go technika wykonania map etnicznych tak, by materiałom dostarczanym przez delegacje bezpośrednio zainteresowanych państw móc przeciwstawić własne, obiektywniejsze. Praktycznym przykładem tych teoretycznych założeń miała być jego mapa narodowościowa terenów rumuńskiej dominacji etnicznej. Już użyte w jej opisie sformułowanie wskazywało, że nie był to owoc jedynie obiektywnego zainteresowania regionem. Istotnie, Martonne przyznawał Rumunom prawo do dominacji na terenie pokrywającym się z późniejszą Wielką Rumunią. Chociaż niezbyt przejrzysta (kolory, cieniowania i barwne pasy na terenach etnicznie mieszanych wprowadzały użytkowników mapy w błąd wskutek technicznych błędów druku), mapa Martonne'a nie pozostawiała wątpliwości, że cały ten teren objęty był zwartym rumuńskim osadnictwem ${ }^{80}$. Opinia geografa okazała się ostatecznie zbieżna ze stanowiskiem konferencji.

Swój wpływ na decyzje polityczne zawdzięczał Martonne nie tylko osobistym zaletom, ale także ufności dyplomatów w jego bezstronność w sporach terytorialnych na wschodzie Europy. Chociaż niektóre jego rekomendacje, jak również zaszczyty, którymi po konferencji obsypało go rumuńskie państwo, zdają się temu przeczyć, w oczach przedstawicieli mocarstw jako Francuz niejako automatycznie był wiarygodny ${ }^{81}$. Upływ czasu i postępujące zmęczenie czołowych polityków sprzyjało symbolicznym i realnym awansom naukowców takich jak Martonne. Pozycja ekspertów umacniała się tym bardziej, im wyraźniej na jaw wychodziła ignorancja mężów stanu.

Ten wdzięczny temat gości w wielu wspomnieniach uczestników konferencji, skądinąd często zafascynowanych wielką polityką. Wielcy tego świata notorycznie mylili sporne regiony, nie wiedzieli czy polsko-niemiecki spór terytorialny dotyczy Górnego, czy Dolnego Śląska, przekręcali nazwy, ze zdziwieniem konstatując, że delegacja Ormian także zgłasza pretensje do Śląska (nieporozumienie wynikłe z powodu podobieństwa angielskich nazw Cylicji i Śląska). Te i podobne lapsusy byłoby zapewne łatwiej wybaczyć, gdyby nie nieustająco dobre samopoczucie wysoko postawionych ignorantów. W rozmowie z Charlesem Seymourem rumuński premier Brătianu z rezygnacją podsumował ich zachowanie, wzdychając, że mimo wagi problemów Rumunii, wielcy mężowie i tak przysną podczas dyskusji nad nimi, z kolei fakt, że

80 G. Palsky, op. cit., s. 111-119.

${ }^{81} \mathrm{~J}$. Bariéty, Le Comité d'Études du Quai d'Orsay et les frontiers de la Grande Roumanie, 1918-1919, „Revue Roumaine d'Histoire” 35, 1996, 1-2, s. 43-51. 
przysnęli i tak nie powstrzyma ich przed podjęciem decyzji w naszej sprawie $^{82}$. Wrażliwsi obserwatorzy z trudem znosili stosunki panujące podczas obrad. Seton-Watson wspominał: „Bez względu na to, jak długo przyjdzie mi jeszcze żyć, mam nadzieję, że już nigdy nie będę zmuszony przebywać w takiej atmosferze. Prawdziwy Paryż pokryła fala brudnych intryg i kłębowisko małych ludzi na ważnych pozycjach krążących wokół kilku osobistości wielkich, lecz skarlałych i wyjałowionych przez bezprzykładny wysiłek"83.

Na tym tle eksperci ze wschodu Europy sprawiali wprawdzie wrażenie profesjonalistów, ale ich obiektywizm budził poważne wątpliwości. Isaiah Bowman, główny ekspert delegacji amerykańskiej, wspominał:

Każda z narodowości Europy Środkowej dysponowała swoim własnym zasobem statystycznych i kartograficznych sztuczek. Tam, gdzie zawodziła statystyka, używano kolorowych map. Trzeba by obszernej monografii, by pomieścić analizę wszystkich typów fałszerstw dokonywanych na mapach, wywołanych przez potrzeby wojny i pokoju. Odkryto nowe narzędzie język mapy. Mapa była równie skuteczna, jak krzykliwy plakat, ale sam fakt, że była mapą, czynił ją godną zaufania, autentyczną. Podkręcona mapa stała się nośnikiem niejednego poronionego rozumowania. Proces ów przejawiał się w sposób najbardziej jaskrawy na Bałkanach ${ }^{84}$.

Atmosfera podejrzeń, najczęściej uzasadnionych, co do uczciwości partnerów z Europy Środkowo-Wschodniej i Bałkanów utrudniała tym ostatnim skuteczne działanie. Zmuszała ich do szukania okrężnych dróg wpływu na decyzje konferencji. Najpopularniejszą stała się ścieżka od eksperta do eksperta.

${ }^{82}$ C. Seymour, Letters from the Paris Peace Conference, oprac. H.B. Whiteman, Jr., New Haven-London 1965, s. 156.

83 „However long I may live, I hope I shall never breathe such an atmosphere again. The true Paris had been submerged by a wave of fetid intrigue, and a babel of small men in big positions surged round a few big men whom the strain of an anexampled crisis had made small and sterile", Ch. Seton-Watson, H. Seton-Watson, The Making of a New Europe. R.W. Seton-Watson and the Last Years of Austria-Hungary, Seattle 1981, s. 344.

84 „Each one of the Central European nationalities had its own bagful of statistical and cartographical tricks. When statistics failed, use was made of maps in colour. It would take a huge monograph to contain an analysis of all the types of map forgeries that the war and the peace conference called forth. A new instrument was discovered the map language. A map was as good as a brilliant poster, and just being a map made it respectable, authentic. A perverted map was a life belt to many a foundering argument. It was in the Balkans that the use of this process reached its most brilliant climax", cyt. za: G. Palsky, op. cit., s. 113. 


\section{Między nami ekspertami}

Obraz obrad paryskich jako zmagań zaprawionych w bojach dyplomatów jest w pewnym stopniu uprawniony. Równie dobrze możemy jednak, zamiast patrzeć na geografów oczami polityków, odwrócić perspektywę. Co się stanie, jeśli na planie pierwszym umieścimy nie polityczną walkę, ale geografię? Wówczas pole działania uczonych znacząco się powiększy. Dostrzeżemy bowiem wszystkie te okazje, kiedy występowali nie w cudzej, lecz we własnej roli, nie jako politycy, lecz naukowcy. Na czym mógł polegać ten sposób zaangażowania w negocjacje, pokazał w pewnym sensie opis sporu pomiędzy Cvijićiem i Martonne'em o podział Kotliny Klagenfurckiej. Ich dyskusja w pewnym momencie przeistoczyła się ze standardowego sporu terytorialnego w polemikę metodologiczną. Nie był to pierwszy przypadek, kiedy naukowy autorytet geografów pośrednio wpłynął na stanowisko mocarstw. Poprzedni miał miejsce w innych okolicznościach i znacznie wcześniej.

Pod koniec 1917 r. Bowman, prezes Amerykańskiego Towarzystwa Geograficznego, wysłał list do przebywającego w Paryżu Cvijićia. Mając na uwadze rozpoczęte właśnie prace Inquiry, Bowman zwrócił uwagę na etnograficzną mapę Bałkanów, przesłaną przez Serba do publikacji w „Geographical Review”85. Niemal natychmiast w ślad za pierwszym listem wysłał do Paryża kolejny:

Towarzystwo - pisał - prowadzi obecnie pewne badania nad etnografią i podziałem narodowościowym Europy i chętnie dowiedziałbym się, czy byłby Pan gotów w badaniach tych pomóc. Pańska znakomita mapa Półwyspu Bałkańskiego jest tak interesująca, że mam nadzieję, iż dałoby się rozciągnąć Pańskie studia etnograficzne dalej na północ.

Czy mógłby pan przygotować mapę etnograficzną Europy Środkowej, rozciągającą się na północy poza granicę mapy, którą dysponuje Pan obecnie, aż do wybrzeży Bałtyku, włączając wschodnie prowincje Austro-Węgier, Polskę oraz Rumunię i południową Rosję? [--] We wszystkich tych pracach, zarówno w przypadku Bałkanów, jak i Europy Środkowej wraz z Polską, nieodzowne będą odwołania do źródeł tak, aby można było mapę zweryfikować w każdym punkcie. Mapy powinny zostać przygotowane w odpowiedniej skali, aby wyraźnie pokazywać wszystkie szczegóły ${ }^{86}$.

85 American Geographical Society of New York Records (dalej: AGS), Directors' Files, Isaiah Bowman, sygn. cyf. AGSNY_B183_F028_004.01.

86 „This Society has under way some investigation of European ethnography and nationality, and I should like to know whether you can give us further assistance. Your excellent map of the Balkan Peninsula is so interesting that I hope it is possible for you to extend your ethnographic studies further north. 
Cvijić przyjął amerykańskie zamówienie (do czego bez wątpienia zachęcało również wysokie wynagrodzenie, obiecane mu przez Bowmana) i wywiązał się ze zobowiązania, dostarczając mapę w połowie $1918 \mathrm{r}$. Jej wykorzystanie obwarował jednak pewnym warunkiem:

Mapa etnograficzna Europy w skali 1:1 000 000, którą Pan szczęśliwie otrzymał, nie jest przeznaczona do publikacji pod moim nazwiskiem. Wykonałem ją tylko dla Pańskich aktualnych potrzeb. Jasno zaznaczyłem, że mapa dotyczy Półwyspu Bałkańskiego, Austro-Węgier i Rumunii, regionów, które przez dłuższy czas badałem i które dobrze znam. Pod moim nazwiskiem może się ukazać wyłącznie mapa ograniczona do tych regionów. Co do pozostałych terytoriów aż do Bałtyku, proszę ją traktować jedynie jako materiał pomocniczy, do którego w pracach członków Pańskiego Towarzystwa należy podchodzić krytycznie. Ta część mapy etnograficznej nie nadaje się jeszcze do publikacji. Są tam detale, wciąż jeszcze wymagające badań nad słowiańsko-niemieckimi kwestiami etnicznymi i statystyką ${ }^{87}$.

Właśnie podobne okoliczności umożliwiały geografom wywieranie wpływu na bieg wydarzeń politycznych nie za pomocą przekonywania polityków czy też dostarczania im amunicji do polemik, lecz poprzez kontakt z innymi geografami, ekspertami mocarstw i mniejszych państw. Bardzo ciekawym zapisem takiego właśnie udziału w konferencji jest Pamiętnik paryski Eugeniusza Romera. Autor opisał w nim na przykład swoje relacje z czeskim geografem, Viktorem Dvorskim. Pierwsze spotkanie przyszłych ekspertów dwóch państw reprezentowanych w Paryżu miało miejsce przed ogłoszeniem dokładnej daty i miejsca obrad

Can you make an ethnographic map of central Europe extending north from the limits of the map now in our hands as far as the Baltic coast. Including East Austria-Hungary and Poland as well as Roumania and Western Russia? [--] In all this work, both on the Balkans and on Central Europe including Poland, it would be necessary to give reference to sources so that every point could be verified. The maps ought to be on a sufficiently large scale to show all details clearly", AGS, Directors' Files, Isaiah Bowman, sygn. cyf. AGSNY_B183_F028_006.01-03, List Bowmana do Cvijićia, 19 XII 1917.

87 „The ethnographic map of Europe, 1:1,000,000 which you have safely received is not intended to be published under my name. I did it to serve your immediate purposes. I clearly stated that the map was distinctly for the Balkan Peninsula, Austria-Hungary and Rumania, the regions which I have for a long time studied and which I know. Only an ethnographic map confined to these regions may be published under my name. For the other regions as far as the Baltic Sea it may be used only as working stock, the material to be chosen with rigorous criticism for the studies of the members of your Society. There are details which still need study on the Slav and German ethnography questions, as well as the statistics", AGS, Directors' Files, Isaiah Bowman, sygn. cyf. AGSNY_B183_F028_015.01, List Cvijićia do Bowmana, 20 VI 1918. 
konferencji pokojowej, we Lwowie w październiku 1918 r. Kilka tygodni wcześniej na wiecu miejscowego Sokoła pojawił się czeski dziennikarz i działacz polityczny Vladimír Sis. W rozmowie z Romerem, z którym się zresztą zaprzyjaźnił, zapowiedział wizytę praskiego docenta, pragnącego zaczerpnąć informacji o metodach badawczych Romera. Jednak Dvorský, kiedy już się zjawił, nie wzbudził w Romerze ciepłych uczuć:

Na moje wywody dotyczące granic etnograficznych a nie mniej na wywód metod i kryteriów naukowych, na podstawie których przebieg granic etnograficznych został ustalony, p. Dvorský zupełnie nie reagował, dyskusji w tym kierunku zupełnie nie podejmował, a natomiast usiłował przekonać mię do innego, geograficznego uzasadnienia praw czeskich do śląska Cieszyńskiego. Dvorský wywodził mianowicie, że geograficzną kontrolą terytorium państwowego czeskiego są górne baseny rzeczne. Takim oto basenem jest nie tylko Kotlina Czeska, takim basenem są Morawy, takim są też wszystkie ziemie Słowaczyzny, które nigdzie poza górne biegi dolin nie wykraczają, takim górnym basenem Odry i Wisły jest też Śląsk Cieszyński, którego tedy przynależność do państwa czecho-słowackiego nie tylko ze względów historycznych, ale i ze względów fizjograficznych jak najzupełniej uzasadniona. Nie było trudno zbić wywody Dvorskiego. [--] Wystarczyło wykazać, że z chwilą gdy porzucimy kryteria etnograficzne, a staniemy na gruncie kryteriów Dvorskiego, to z powodu położenia Czech na głównym europejskim dziale wodnym nie ma dla państwa czeskiego w ogóle żadnej w Europie granicy. Także zwrócenie uwagi na to, że podstawą każdego ustroju politycznego są możliwie najkorzystniejsze warunki komunikacyjne, wiążące państwo w całość gospodarczą, obalało od razu koncepcję Dvorskiego, która jako zasadę fizjograficzną dla państwa stawiała warunki terytorialne z możliwie niekorzystnymi warunkami naturalnymi dla komunikacji ${ }^{88}$.

Czeski geograf wciąż nie był jeszcze przekonany, kiedy Romer, jak zwykle zajęty pilną pracą, stracił nim zainteresowanie i odesłał gościa do swojego asystenta, Stanisława Pawłowskiego. „Toku rozmowy dwu młodych geografów ze sobą nie znam bliżej - wspomina dalszy ciąg wizyty - pomnę tylko tyle, że w pracy, której się wnet oddałem, przeszkadzał mi podniesiony głos w sąsiednim pokoju dyskutujących panów. Po pewnym czasie rozłączyłem wojujące strony, sądząc z zewnętrznego wyglądu, szczerze rozognione"89.

Mimo obustronnego zaperzenia, w sporze tym Romer i Pawłowski najwyraźniej skutecznie przekonali Dvorskiego do swoich racji. W wydanej

${ }^{88}$ E. Romer, Pamiętnik paryski (1918-1919), oprac. A. Garlicki, R. Świętek, Wrocław 1989, s. 78-79.

${ }^{89}$ Ibidem, s. 79. 
jeszcze w 1918 r., w chwili ich spotkania być może już złożonej do druku, pracy Území českého národa teoria górnego biegu rzek jest reprezentowana głównie za pomocą mapy. Natomiast w tekście Dvorský dość oszczędnie używa argumentu, którym posługiwał się we Lwowie, gromadząc za to cały szereg innych dowodów na jedność ziem czeskich i słowackich. Obok geologii i przyrody zaliczały się do nich także tezy antropogeograficzne dotyczące kultury i psychologii ludzi zamieszkujących powstające państwo ${ }^{90}$. Efekt rozmowy z polskimi kolegami wyraźniej widać za to w czechosłowackich memorandach złożonych przed przedstawicielami mocarstw kilka miesięcy później, których Dvorský był współautorem. W nich teoria górnego biegu rzek w ogóle się nie pojawiła.

Już w Paryżu Romer wielokrotnie stykał się z ekspertami delegacji francuskiej, amerykańskiej i rumuńskiej, okazjonalnie także z kolegami z innych państw. Do poważniejszego spotkania doszło w połowie stycznia 1919 r. Krótko przedtem Romer spotkał się z Bowmanem, wręczając mu egzemplarz swojego atlasu (i wysłuchując pełnych zachwytu uwag jego ówczesnego asystenta, Parkera Thomasa Moona). Kilka dni później doszło do ponownej rozmowy, na proszonym obiedzie wydanym przez delegację Kolumbii:

Przy stole siedziałem na życzenie Bowmana przy nim i rozmawiałem na temat Litwy. Zwracałem uwagę na osiowy charakter terytorialny polskich większości na Litwie i [--] na konsekwencje takiego układu: albo całe dawne Wielkie Księstwo Litewskie złączy się z Polską, albo Litwa pozostanie nieżywotną, gdyż Polska nie może zrezygnować ze swego obszaru etnograficznego, a części Białorusi prawosławnej będą miały tendencje powrotu do Rosji. [--

Dyskusja toczyła się głównie na temat Rumunii i Dunaju. [Ludovic] Mrazec bronił pretensji rumuńskich do całego obszaru Banatu, podnosząc zasadę, że państwo powinno posiadać wszystkie klucze do swych dróg wewnętrznych, w tym przeto przypadku do ujścia Maroszy (Muresz) do Cisy. Popierałem rozumowanie Mrazeca, narażając się na uwagę [doradcy delegacji amerykańskiej Roberta H.] Lorda, że „ciągle przemyśliwam o Gdańsku”"

Miesiąc później Romer ponownie widział się na kawie z Bowmanem. Tym razem zaprezentował mu wyniki swoich porównawczych badań nad poziomem cywilizacyjnym Polaków, Niemców i Ukraińców. Projekt, wykoncypowany w gorących dniach polsko-ukraińskich walk o Lwów, przy pomocy diagramów dowodził, że w odróżnieniu od Polaków,

90 V. Dvorský, Území českého národa, Praha 1918.

${ }^{91}$ E. Romer, Pamiętnik paryski, s. 114-115. 
Ukraińcy nie osiągnęli jeszcze zdolności do stworzenia funkcjonującego państwa. Logiczna konkluzja wszystkich tych wyliczeń była oczywista: Galicja Wschodnia powinna należeć do Polski. Bowman powstrzymał się od komentarza na temat treści tych materiałów, zainteresował się natomiast metodologią badań i sposobem prezentacji92. Jego podziw raczej nie był udawany. Kilka miesięcy później, w liście do wybitnego geomorfologa Williama Morrisa Davisa, Bowman, podsumowując swoje paryskie przeżycia, poświęcił Romerowi kilka entuzjastycznych uwag ${ }^{93}$. Nie szczędził ich także w korespondencji skierowanej bezpośrednio do polskiego geografa:

Nie mogę zmarnować okazji, że obydwaj przebywamy przez jakiś czas w Paryżu - pisał Bowman pod koniec kwietnia 1919 r. - by powiedzieć $\mathrm{Ci}$, jak wielką pomocą dla amerykańskiego rządu podczas przygotowań do konferencji pokojowej stał się Twój atlas. [--] Odwołanie do Twojego atlasu pod wieloma względami ułatwiło naszą pracę, umożliwiając przygotowanie memorandów o wielu polskich problemach znacznie szybciej niż bylibyśmy w stanie to uczynić $\mathrm{w}$ innej sytuacji. Nie mogę pominąć godnego najwyższego uznania ducha, w jakim utrzymany jest nie tylko atlas, ale także towarzyszące mu tablice statystyczne. Postępowałeś zgodnie z metodą rzadko stosowaną przez młode narodowości, czyli opierając Twoje mapy na opublikowanych statystykach, najczęściej oficjalnych i wyciągając wnioski co do stopnia wiarygodności owych statystyk. Jako geograf pragnę wyrazić podziw dla Twojej pracy i najwyższy szacunek, którym my wszyscy darzymy atlas przygotowany w tak trudnych warunkach ${ }^{94}$.

Takie wymiany listów, a także półoficjalne i nieoficjalne rozmowy przy okazji obiadów, podwieczorków albo i bez szczególnej okazji, miały istotne znaczenie dla obu stron. Eksperci mocarstw uzupełniali braki

92 Ibidem, s. 194.

93 AGS, Directors' Files, Isaiah Bowman, sygn. dig. AGSNY_B183_F031_074.01-02.

94 „I cannot let the opportunity go by while we are both together in Paris of telling you how great a service your atlas rendered to the American government in its preparations for the peace conference. [--] The use of your atlas facilitated our work in many respects, and enabled us to prepare our memoranda on many of Poland's problems much more promptly than we should otherwise have been able to do. I cannot refrain from indicating the commendable spirit in which you prepared not only the atlas but the statistical tables accompanying it. You have proceeded according to a method which few young nationalities have adopted, that is, of basing your maps upon published statistics, chiefly official, and drawing conclusions as to the degree of reliability of the statistics. As a fellow geographer I want to express my warm appreciation of your work and the high esteem in which all of us hold the atlas that you prepared under such difficult conditions", BJ, Eugeniusz Romer, sygn. k. 24, List Bowman do Romera, 30 IV 1919. 
w wiedzy. Romer na przykład korespondował w marcu 1919 r. z Martonne'em, objaśniając mu sposób przedstawienia własności ziemskiej na odpowiedniej karcie swojego atlasu, a także ponownie tłumacząc metody, którymi posłużył się, mierząc polsko-ukraińskie różnice cywilizacyjne ${ }^{95}$. Dzięki takim darmowym korepetycjom z większym spokojem mogli czekać na wezwanie mężów stanu, żądających błyskawicznej, zwięzłej i treściwej informacji w zagmatwanych kwestiach granicznych. Z kolei dla ekspertów delegacji państw na dorobku każda okazja do konfrontacji z wyżej postawionymi kolegami naukowcami stawała się powodem do satysfakcji, dając nadzieję na pomyślny kształt ostatecznych postanowień konferencji. Także ci członkowie delegacji, którzy z racji pełnionych obowiązków rzadko uczestniczyli w podobnych spotkaniach, opisywali radosne podniecenie kolegów dopuszczonych do elitarnego kręgu ekspertów mocarstw. „Romer wpadł do Biura rozpromieniony i rozczulony, że Bowman całą duszą nasz i że nie może wyjść z podziwu z powodu Lwowa" - notował Konopczyński po marcowym spotkaniu polskiego i amerykańskiego geografa ${ }^{96}$.

Kontakty ekspertów mocarstw z kolegami z mniejszych państw nie polegały wyłącznie na poklepywaniu po plecach i wyrazach uznania za wykonaną pracę. Tam, gdzie jej poziom nie budził zaufania, dochodziło do otwartych scysji. Romer relacjonuje jedno z takich starć, do którego przyczynił się jego kolega, Jan Czekanowski. Lwowski antropolog pełnił w gronie polskich ekspertów nieoficjalną rolę komisarza politycznego. Politycznie bliski Dmowskiemu, dał się poznać jako człowiek dobrze zorientowany w zakulisowych rozgrywkach polskiej delegacji. Dla Romera liczył się jednak przede wszystkim jego merytoryczny wkład w prace kongresowe. Ten polegał na przygotowaniu projektu rozgraniczenia polskiego terytorium etnicznego od terenów niepolskich. Pod względem metodologicznym podejście Czekanowskiego było ciekawe, wykazywało zresztą pewne podobieństwo do metody izarytm stosowanej przez Romera ${ }^{97}$. Lwowski antropolog zaproponował podział wzdłuż „linii równowagi etnograficznej”, przyznający obu stronom terytorium proporcjonalne do liczby zamieszkującej tam ludności danej narodowości. Problem w tym, że jego równowaga okazała się chwiejna, przechylając się bardzo mocno na polską stronę. Romer był smutny i wściekły. 29 kwietnia 1919 r. notował:

${ }_{95}$ BJ, Eugeniusz Romer, sygn. d. 63, List Romera do Martonne'a, 27 III 1919; sygn. d. 64, List Romera do Martonne'a, 30 III 1919.

96 W. Konopczyński, op. cit., s. 328.

97 M. Labbé, op. cit., passim. Zob. przyp. 22. 
Po południu u Lorda. Odkrył bezpodstawność całej kalkulacji etnograficznej Czekanowskiego, [--] równocześnie zarzut przeciw Pawłowskiemu, który użył w swym studium nad Galicją Wschodnią barwy czerwonej dla gmin z 25-50 proc. Polaków, niczym nie usprawiedliwiony. Opowiadał też, że Martonne przyszedł na komisję z mapą sfałszowaną na odwrót, znacząc gminy ruskie w 25-50 proc. błękitem! Nasz obraz stracić musiał oczywiście nie tylko formalnie na takiej rektyfikacji.

Doznawałem wrażenia, że te pierwsze rysy w naszych budowlach naukowych spowodowały rysy i w atmosferze stosunków osobistych. [--] Nie pozbawiony bowiem już od dawna pewnych pytajników co do założeń, na których oparte były studia Czekanowskiego, utrzymywałem się do ostatniej chwili w przekonaniu, że ludność nadziałowa jest ilościowo proporcjonalna do powierzchni zajmowanej przez nią ziemi, z której to iluzji dopiero Lord w sposób bardzo dotkliwy mię wyzwolił ${ }^{98}$.

Troska o dobre stosunki z amerykańskimi kolegami, przebijająca z reakcji geografa, dobrze ilustruje złożony charakter udziału ekspertów w paryskich negocjacjach. Ważyły się nie tylko losy ojczyzny. Na szali znajdował się również prestiż rodzimej nauki i osobisty prestiż poszczególnych uczonych. Nie tylko Romer wyraźnie zdawał sobie sprawę, że bez względu na decyzje konferencji, po jej zakończeniu trzeba będzie wrócić do życia i pracy. I jedno, i drugie rysowało się w jaśniejszych barwach przed tymi ekspertami, do których nie przylgnęła łatka fałszerzy.

Ta podwójna lojalność - wobec rodzinnego kraju oraz wobec nauki dawała o sobie znać szczególnie dobitnie właśnie w kontaktach ekspertów z Europy Środkowo-Wschodniej i Bałkanów z kolegami reprezentującymi zwycięskie mocarstwa. Korespondencja pomiędzy nimi w czasie negocjacji paryskich i bezpośrednio po ich zakończeniu wyraźnie dzieli się na trzy wątki. Pierwszy to polityka, traktowana najczęściej jak dopust boży, uciążliwa przeszkoda w powrocie do pracy naukowej. „Moim serdecznym życzeniem był zupełny powrót do nauki i wykładów. Niestety - ententa na to nie pozwoliła!" - skarżył się w liście do Bowmana Romer, wściekły

${ }^{98}$ E. Romer, Pamiętnik paryski, s. 293. W późniejszej recenzji z mapy Pawłowskiego Romer uściślił tę relację: „Cel zamierzony osiągnięto, ale w paryskim «Comité d'études» pracującym dla francuskiego Ministerium Spraw Zagranicznych podczas Konferencji pokojowej opracowano na podstawie materiału karty Pawłowskiego dwie inne karty dyskusyjne, jedną zupełnie obiektywną, w której zmiana kolorów, oznaczająca Polaków i Rusinów dokonywała się przy 50 proc., a drugą, uwzględniającą przeciwnie niż mapa Pawłowskiego, tylko najsilniejsze większości polskie, tzn. oznaczającą jako polskie tylko te osady, które liczą ponad 75 proc. ludności rzymsko-katolickiej”, E. Romer, rec. z: S. Pawłowski, Ludność rzymsko-katolicka w polsko-ruskiej części Galicji (1919), „Polski Przegląd Kartograficzny" 1, 1923-1924, 2, s. 71. 
na kompromisowe rozwiązania przyjęte przez mocarstwa w kwestii Gdańska, Górnego Śląska i Galicji Wschodniej ${ }^{99}$. Drugi, nie mniej istotny wątek, dotyczył prac własnych. Zarówno Romer, jak i Cvijić zabiegali o anglojęzyczne publikacje swoich prac, zajmowali się ich dystrybucją i z wdzięcznością przyjmowali gratyfikacje i niematerialne dowody uznania. Najczęściej chodziło o medale, przyznawane przez towarzystwa geograficzne ekspertom zasłużonym w pracach przygotowawczych i kongresowych. Otrzymywali je prawie wszyscy interesujący nas uczeni. Jednym z najbardziej niezwykłych przejawów naukowego hołdu było nadanie imienia Romera lodowcowi na Alasce ${ }^{100}$. Trzeci motyw korespondencji nie miał nic wspólnego z osobistymi ambicjami. Sądzę, że należałoby go traktować raczej jak przejaw patriotyzmu, nie mniej ważny niż zaangażowanie geografów w dyskusje graniczne. Chodzi o ich wysiłki na rzecz odnowienia życia naukowego w kraju nie tylko zniszczonym przez wojnę, ale także dotkniętym galopującą inflacją, panoszącym się bandytyzmem i konfliktami społecznymi. Pál Teleki, podróżujący do Paryża w składzie węgierskiej delegacji mającej usłyszeć wyrok mocarstw, właśnie w tej sprawie zwrócił się do Bowmana:

Piszę do Pana z pociągu wiozącego naszą delegację do Paryża. Amerykańska Misja Wojskowa z Budapesztu podróżuje tym samym składem, poproszę więc tych panów, by zabrali ze sobą ten list. Wie Pan, jak fatalnie przedstawia się nasza waluta. To fatalne nie tylko dla gospodarki, ale i dla nauki i pracy naukowej. Po doświadczeniu bolszewizmu i rumuńskiej dewastacji, straciliśmy znaczną część naszego wyposażenia naukowego i bibliotek. Bardzo trudno wszystko to obecnie odbudować, a jeszcze trudniej o nowe publikacje. Chciałbym zwrócić pańską uwagę oraz uwagę amerykańskiego świata nauki na te fakty prosząc, czy nie rozważyłby Pan zwrócenia się do autorów i instytucji o przysyłanie kopii swoich wydanych ostatnio publikacji na Węgry ${ }^{101}$.

99 AGS, Directors' Files, Isaiah Bowman, sygn. cyf. AGSNY_B187_F035_001.01, List Romera do Bowmana, 17 XII 1919.

100 AGS, Directors' Files, Isaiah Bowman, sygn. cyf. AGSNY_B187_F035_031.03, List Bowmana do Romera, 1 XI 1923.

101 „I am writing to you on the train of our peace Delegation going to Paris. There is travelling on the same train the American Military Mission from Budapest and I will ask these gentlemen to take this letter with them to you. You know how badly our valuta is standing. This is detrimental not only in economics but also in science and scientific work. Having gone through bolshevism and Roumanian devastation we have lost very much of our scientific equipment and libraries. It is very difficult to restitute all that now and still more difficult to have at least the same time all the new obligations. I would call your attention and that of the American scientific world on these 
Podobne prośby docierały do amerykańskich i francuskich ekspertów z różnych stron i z reguły były wysłuchiwane, mimo rozmaitych trudności. Doświadczyła ich na przykład paczka dubletów „Geographical Review" wysłanych przez Bowmana do Lwowa na prośbę Romera jeszcze w 1919 r. O dziwo, mimo trwających wciąż walk i dezorganizacji kraju, przesyłka najwyraźniej do Lwowa dotarła, skąd jakiś urzędnik pocztowy odesłał ją do Nowego Jorku. Bowman pisał w tej sprawie do Romera:

Gott im Himmel! Donnerwetter! Parbleu! Mon Dieu! Sacré Bleu! Carramba! Hell! Czemu, drogi przyjacielu, usługi pocztowe we Lwowie wciąż są tak fatalne, że dadzą się porównać chyba tylko z samym Nowym Jorkiem, gdzie za sprawą destruktywnego wpływu wojny i zwrócenia uwagi na inne sprawy, usługi upadły tak nisko, że wysyłając list z jednego miejsca nie możemy mieć pewności, czy dotrze do osoby mieszkającej po drugiej stronie ulicy. Błagam Cię, drogi przyjacielu, zaangażuj się w sprawy administracji i nie dopuść do tego, by Twój nowy rząd i nowi urzędnicy okazali się tak samo głupi, jak ci, którzy obecnie rządzą krajem ${ }^{102}$.

W drugą stronę wędrowały publikacje wydawane w Europie Środkowo-Wschodniej i na Bałkanach, przyczyniając się do umiędzynarodowienia wyników pracy miejscowych naukowców. Prosty i funkcjonujący do dziś mechanizm wymiany gładko wszedł w koleiny wyżłobione już przed wojną. Jedyna różnica dotyczyła odbiorcy. Przed wojną publikacje z regionu posyłano najczęściej do naukowców niemieckich, teraz ich miejsce zajęli Francuzi i - po raz pierwszy w takim stopniu - Amerykanie. Ożywiły się także stosunki pomiędzy geografami z Europy Środkowo-Wschodniej i Bałkanów. Bezpośrednio po wojnie kontakty pomiędzy Cvijićiem, Romerem, Dvorským, Simionem Mehedinţim i innymi obywały się już zupełnie bez pośrednictwa. Za każdym z nich stał nie tylko własny autorytet naukowy, ale i instytucje badawcze i polityczne.

facts and ask you if it would not be possible to ask institutions and authors to be so kind as to send some copies of the work written or published by them to Hungary", AGS, Directors' Files, Isaiah Bowman, sygn. cyf. AGSNY_B189_F009_003.01-03, List Telekiego do Bowmana, 10 II 1920.

102 „Gott im Himmel! Donnerwetter! Parbleu! Mon Dieu! Sacre Bleu! Carramba! Hell! Why, my dear friend, your postal service in Lemberg is so bad that I can only compare it with that of New York itself, where, on account of the disturbing influence of the war and the diversion of humanity into new channels, we have a service so wretched that we cannot be sure that a letter mailed in one block will reach a person living across the street. I beg of you, my dear Romer, to interest yourself in government matters and not to allow your government and your new officials to become so stupid and inefficient as those who run this country at the present time", AGS, Directors' Files, Isaiah Bowman, sygn. cyf. AGSNY_B187_F035_009.02, List Bowmana do Romera, 19 VI 1920. 
Konferencja pokojowa wywarła na geografów zapewne większy wpływ niż oni na jej końcowe postanowienia. Zapewne, bo tak naprawdę trudno tu o jednoznaczne odpowiedzi. Dokładne ustalenie, kto i w jakim stopniu przesądził o takim czy innym przebiegu granicy, nie wydaje się możliwe. Ostateczne brzmienie traktatów kończących Wielką Wojnę było wypadkową wielu różnych politycznych interesów, sympatii i antypatii, a także stereotypów. Nie bez znaczenia okazała się ignorancja polityków, cecha, której nie wstydzili się ani przedstawiciele mocarstw, ani Dmowski. Eksperci, nigdy wcześniej nieuczestniczący w podobnych obradach tak licznie, zajmowali pośrednią i raczej niezbyt pewną pozycję. Mieli wypełniać luki w wiedzy, odpowiadać na pytania zadawane przez dyplomatów. Rozstrzygnięcia polityczne nie były ich udziałem, wyjątek stanowiła możliwość sformułowania oficjalnego stanowiska delegacji.

A jednak przynajmniej niektórzy z nich nie byli zupełnie bezsilni. Wraz z przeciągającymi się negocjacjami rosła rola ekspertów zwycięskich mocarstw. Oni nie byli mężami stanu i na ogół w ogóle nie czuli się politykami. Być może właśnie ten brak pewności siebie, odróżniający ich od dyplomatów, okazał się ich największą zaletą. Taka myśl pobrzmiewa w niektórych ocenach prac konferencji. Taline Ter Minassian zauważa, że chociaż nie byli w stanie (ani nie próbowali) występować przeciwko politykom, w niektórych przypadkach eksperci odegrali kluczową rolę w doprecyzowaniu posunięć, z którymi się zgadzali ${ }^{103}$. Moon, w Paryżu asystent Bowmana, wyraził zapewne nie tylko swoje własne zdanie, pisząc niedługo po zamknięciu obrad:

I, wreszcie, wydaje się oczywiste, że „eksperci” także nie byli wolni od ludzkich emocji. Byli to naukowcy, pospiesznie i niekiedy nieroztropnie oderwani od książek, by tworzyć nowe prawa dla archaicznego świata. Niektórzy byli do tego przygotowani lepiej, inni gorzej, z pewnością nie wszyscy reprezentowali profesjonalną elitę swoich dyscyplin w Ameryce. Mimo to z reguły okazali się lepszymi mężami stanu niż profesjonalni dyplomaci ${ }^{104}$.

103 T. Ter Minassian, op. cit., s. 252-286, tu s. 286.

104 „And, finally, it is obvious that the «experts» were not impervious to human emotions. They were scholars hastily and in some cases injudiciously summoned from their books to legislate for an anarchic world. Some were well prepared, some ill, and certainly not all were the foremost American authorities in their respective fields. Yet as a rule they proved themselves more statesmanlike than many professional diplomats”, P.T. Moon, More Light on the Peace Conference, „Political Science Quaterly” 36, 1921, 3, s. 501-508, tu s. 508. 
Za sprawą ekspertów mocarstw obrady konferencji pokojowej nabrały specyficznego charakteru, innego niż wcześniejsze kongresy. W pewnym stopniu do głosu doszły zasady, o które w 1914 r. upominał się w swoim londyńskim wykładzie Lyde. Już nie tylko przewaga negocjacyjna i kunszt dyplomatyczny przesądzały o przebiegu granic. Argumenty geograficzne przebiły się przez mur zawodowej dyplomacji.

Jako naukowcy, eksperci mocarstw czuli się w obowiązku uzupełniać wiedzę. Europa Środkowo-Wschodnia i Południowo-Wschodnia stanowiła w niej jedną z większych luk. Nic w tym dziwnego; nawet stosunkowo najlepiej zorientowani geografowie niemieccy potrafili wykazywać się na tym polu zadziwiającą ignorancją. A w Paryżu ich przecież nie było.

Deficyt informacji potrzebnych ekspertom mocarstw i ich politycznym zwierzchnikom zwrócił ich uwagę na znacznie lepiej zorientowanych kolegów. Tu właśnie otworzyła się przestrzeń dla aktywności specjalistów z Europy Środkowo-Wschodniej i Bałkanów. Dwaj najbardziej energiczni i najwybitniejsi, Jovan Cvijić i Eugeniusz Romer, przyjechali do Paryża już jako autorzy znakomitych dzieł kartograficznych. Nawiązanie profesjonalnych i osobistych kontaktów z ekspertami USA, Francji czy Wielkiej Brytanii nie stanowiło dla nich problemu. Wykorzystywali je, prezentując zachodnim kolegom własne interpretacje geograficznych podziałów regionu, a zarazem swoje wyobrażenie o jego przyszłych granicach. Także później uczestniczyli w dyplomatycznych negocjacjach dotyczących przebiegu tych granic, których ostatecznego kształtu nie ustalono w Paryżu ${ }^{105}$.

Wprawdzie w łańcuchu decyzyjnym konferencji pokojowej ekspertów od geografii należałoby zapewne umieścić bliżej szarego końca niż początku. Oficjalnie nie odgrywali wszak właściwie żadnej roli. Jednak w porównaniu z polityczną częścią swoich delegacji bynajmniej nie wypadali najgorzej. Nie tylko w polskim przypadku pomiędzy grupą ekspertów a zawodowymi politykami dochodziło do napięć. Romer wspominał jedno z mniej przyjemnych spotkań z Dmowskim, który zamiast podjąć rzeczową dyskusję z polskimi specjalistami, zaszachował ich krótką sentencją: „Mąż stanu nie ma czasu sprawy studiować!” ${ }^{106}$. Geograf zanotował, jak fatalne wrażenie zrobiło zachowanie „męża stanu” na zgromadzonych naukowcach. Energiczna i agresywna osobowość Dmowskiego w ogóle budziła zresztą mieszane uczucia wśród zgromadzonych w Paryżu dyplomatów i naukowców, czasami narażając na szwank interesy, które

105 B. Pasierb, Profesor Eugeniusz Romer jako konsultant na rokowania pokojowe w Rydze, w: Traktat ryski 1921 roku po 75 latach, red. M. Wojciechowski, Toruń 1998, s. 89-109.

106 E. Romer, Pamiętnik paryski, s. 185. 
reprezentował ${ }^{107}$. Konfrontacja różnych relacji z przebiegu obrad skłania do sceptycznej oceny faktycznych dokonań skądinąd wybitnych polityków. Zabawnym przykładem może być Polityka polska $i$ odbudowanie państwa, dzieło którym Dmowski skutecznie utrwalił swój wizerunek demiurga polskiej niepodległości. 29 stycznia 1919 r. Dmowski miał okazję przedstawić polskie stanowisko przed obliczem Rady Najwyższej: „Mówiłem po francusku - wspominał. - Po jakichś dziesięciu minutach mego przemówienia [Georges] Clemenceau przerwał, zwracając się do tłumacza o przełożenie mych słów na język angielski. Wtedy zapytałem, czy mogę sam przetłumaczyć. Mówiłem tedy na przemian w dwóch językach, tłumacząc bądź z francuskiego na angielski, bądź odwrotnie, co sprawiło, że przemówienie moje trwało podwójną ilość czasu"108.

Wystąpienie, dla mówcy ewidentnie będące powodem do dumy i osobistej satysfakcji, wywarło całkiem inne wrażenie na słuchaczach. Bowman, uczony doświadczony i raczej nawykły do wykładów, pisał o tym samym występie: „Kiedy Dmowski relacjonował polskie postulaty, zaczął o 11 w XIV w. aby dotrzeć do roku 1919 i aktualnych palących problemów dopiero o 4 po południu. Tuż po nim mówił [Eduard] Beneš przedstawiając żądania Czechosłowaków. O ile dobrze pamiętam, zaczął o stulecie wcześniej i skończył godzinę później"109.

Dmowski nie był wyjątkiem. Podobne problemy z odnalezieniem się w sytuacji odmiennej od własnych wyobrażeń o wielkiej polityce przeżywał na przykład Karel Kramár ${ }^{110}$. Abstrahując od osobistych cech charakteru poszczególnych polityków, warto postawić pytanie, czy niezachwiana pewność siebie i przywiązanie do polityki gabinetowej w przypadku dyplomatycznych przedstawicieli mało znaczących państw wciąż jeszcze odpowiadało duchowi czasu? Czy naprawdę tyrady Dmowskiego, Pašićia czy Ante Trumbićia wywarły większy wpływ na decyzje mocarstw niż materiały przygotowane przez geografów i ich bezpośrednie, zakulisowe spotkania z innymi ekspertami?

107 K. Lundgreen-Nielsen, The Polish Problem at the Paris Peace Conference. A Study of the Policies of the Great Powers and the Poles, 1918-1919, Odense 1979 (oryg. duński 1977), s. 304-306.

108 R. Dmowski, op. cit., s. 128.

109 „When Dmowski related the claims of Poland, he began at eleven o'clock in the fourteenth century, and could reach the year 1919 and the pressing problems of the moment only as late as four o'clock in the afternoon. Beneš followed immediately with the counter claims of Czecho-Slovaks, and, if I remember correctly, he began a century earlier and finished an hour later", cyt. za: S. Seegel, op. cit., s. 279.

110 M. Hronský, Boj o Slovensko a Trianon 1918-1920, Bratislava 1998, s. 206. 
Geografów od polityków odróżniała jeszcze jedna okoliczność. Nawet pogrążeni w wirze negocjacji nie zapominali, że nie służą tylko jednemu panu. Zabiegi o korzystny przebieg granic szły w ich przypadku ręka $\mathrm{w}$ rękę z niegasnącym zainteresowaniem metodologią i pracą na rzecz odbudowy rodzimej nauki ze zniszczeń wojennych. Korespondencja z wysoko postawionymi ekspertami mocarstw dostarcza licznych ilustracji tego rozdwojenia. Co ważniejsze, to właśnie metodologia najbardziej interesowała zachodnich kolegów i dopiero za sprawą tego zainteresowania można było myśleć o przekonaniu ich do swoich postulatów terytorialnych. Znowu najlepszym przykładem tego mechanizmu mogą być Cvijić i Romer, podziwiani nie za to, jak zmyślnie zaokrąglili postulowany zasięg swoich państw, lecz za profesjonalizm i nowatorstwo swoich prac. Gdyby produkowali wyłącznie „podkręcone mapy”, o których wspominał Bowman, nigdy nie staliby się partnerami do dyskusji.

\section{Streszczenie}

Wybuch I wojny światowej dał geografom impuls do podjęcia dyskusji nad takim przebiegiem granic państwowych, który w przyszłości sprzyjałby utrzymaniu pokoju i politycznej równowagi w Europie. Refleksja ta zajmowała naukowców w Europie Zachodniej na poziomie teoretycznym. W tym samym czasie kilku wybitnych uczonych z Europy Środkowo-Wschodniej i Południowo-Wschodniej (Stepan Rudnic'kyj, Eugeniusz Romer, Jovan Cvijić) opublikowało prace definiujące przyszłe terytoria państwowe ich narodów, odnosząc się przy okazji do kwestii metodologicznych dyskutowanych przez zachodnioeuropejskich kolegów. Ich wojenne publikacje spotkały się z zainteresowaniem specjalistów z obu stron konfliktu. Wkrótce doniosłość kwestii granic stała się oczywista także dla walczących państw, czego wyrazem było powołanie ciał eksperckich, takich jak amerykańska Inquiry czy francuski Comité d'études. Pierwszym odpowiednikiem tych think-tanków w Europie Środkowo-Wschodniej było polskie Biuro Prac Przygotowawczych. Eksperci zwycięskich mocarstw odegrali znaczącą rolę w ustaleniach konferencji pokojowej. Autor wskazuje, że za ich pośrednictwem wpływ na te decyzje uzyskali również czołowi eksperci mniejszych państw Europy Środkowo- i Południowo-Wschodniej.

\section{Cards on the Table. Geography and the Boundaries of New Europe after the First World War}

The outbreak of the First World War led geographers to initiate a discussion about such borders of states that would facilitate the maintenance of international peace and political balance in Europe. This, however, also interested researchers in Europe on a theoretical level. At the same time, several outstanding scholars 
from Central Eastern and South Eastern Europe (Stepan Rudnytskyi, Eugeniusz Romer and Jovan Cvijić) published works in which they defined future territories of their nations with references to methodological questions being discussed by their Western European colleagues. Their war-time publications met with interest among experts of both sides of the conflict. Soon, the significance of the problem of borders also became evident to the belligerent countries, which was reflected in the establishment of expert collegial bodies, such as the American 'Inquiry' of the French 'Comité d'etudes'. The first counterpart of those think-tanks in East-Central Europe was the Polish Bureau for Preparatory Works. The experts of the victorious powers played an important part in the settlements of the peace conference. The author argues that through their agency those decisions were influenced also by leading experts of smaller countries of East-Central and South-Eastern Europe.

Translated by Grażyna Waluga

\section{Bibliografia}

Bariéty Jacques, Le Comité d'Études du Quai d'Orsay et les frontiers de la Grande Roumanie, 1918-1919, „Revue Roumaine d'Histoire” 35, 1996, 1-2, s. 43-51.

Boulineau Emile, Les géographes et les frontières austro-slovènes des Alpes orientales en 1919-1920, „Revue de Géographie Alpine” 2001, 4, s. 173-184.

Boulineau Emile, Un géographe traceur de frontières. Emmanuel de Martonne et la Roumanie, „L'Espace géographique” 2001, 4, s. 358-369.

Cehelskyj Longin, Die großen politischen Aufgaben des Krieges im Osten und die ukrainische Frage, Kroll, Berlin 1915.

Cvijić Jovan, La Péninsule Balkanique. Géographie humaine, Colin, Paris 1918.

Die tschechoslowakischen Denkschriften für die Friedenskonferenz von Paris 1919/1920, oprac. Hermann Raschhofer, Heymann, Berlin 1938.

Dmowski Roman, Polityka polska i odbudowanie państwa, t. 2, oprac. Tomasz Wituch, Pax, Warszawa 1988.

Dvorský Viktor, Území českého národa, Český čtenář, Praha 1918.

Ekspertyzy i materiały delegacji polskiej na konferencję wersalska 1919 roku, oprac. Marta Przyłuska-Brzostek, PISM, Warszawa 2009.

Ginsburger Nicolas, Réseaux académiques et circulations savantes entre guerres et paix (1912-1919). Les expertises de Jovan Cvijić et de ses collègues géographes à travers les cas de Trieste et Fiume, „Cybergeo. European Journal of Geography” 2016 (https:// cybergeo.revues.org/27690).

Górny Maciej, Wielka Wojna profesorów. Nauki o człowieku (1912-1923), IH PAN, Warszawa 2014.

Hanak Harry, Great Britain and Austria-Hungary during the First World War. A Study in the Formation of Public Opinion, Oxford University Press, London 1962.

Hausmann Guido, Das Territorium der Ukraine. Stepan Rudnyc'kyjs Beitrag zur Geschichte räumlich-territorialen Diskurs über die Ukraine, w: Die Ukraine. Prozesse der Nationsbildung, red. Andreas Kappeler, Böhlau, Wien 2011, s. 145-157. 
Herb Guntram H., Under the Map of Germany. Nationalism and Propaganda 1918-1945, Routledge, London-New York 1997.

Hronský Marián, Boj o Slovensko a Trianon 1918-1920, Národné literárne centrum, Bratislava 1998.

Jureit Ulrike, Das Ordnen von Räumen. Territorium und Lebensraum im 19. Und 20. Jahrhundert, Hamburger Edition, Hamburg 2012.

Kapras Jan, o českém státě za války a po válce (soubor článků), Český čtenář, Praha 1925. Konopczyński Władysław, Dziennik 1918-1921, cz. 1, oprac. Piotr Biliński, Paweł Plichta, Muzeum Historii Polski, Ośrodek Myśli Politycznej, Warszawa-Kraków 2016.

Lansing Robert, Die Versailler Friedens-Verhandlungen. Persönliche Erinnerungen, Hobbing, Berlin 1921.

Lundgreen-Nielsen Kay, The Polish Problem at the Paris Peace Conference. A Study of the Policies of the Great Powers and the Poles, 1918-1919, Odense University Press, Odense 1979.

Lyde Lionel W., Types of Political Frontiers in Europe, "The Geographical Journal” 45, 1915, 2, s. 126-139.

Macartney Carlile Aylmer, Hungary and Her Successors. The Treaty of Trianon and Its Consequences 1919-1937, Oxford University Press, Oxford 1937.

Ng Amy, A Portrait of Sir Lewis Namier as a Young Socialist, „Journal of Contemporary History" 40, 2005, 4, s. 621-636.

Palsky Gilles, Emmanuel de Martonne and the Ethnographical Cartography of Central Europe (1917-1920), „Imago Mundi” 54, 2002, s. 111-119.

Pasierb Bronisław, Polskie prace przygotowawcze do Traktatu Pokojowego z Niemcami 1916-1948. Instytucje - ludzie - problemy, Wydawnictwo Uniwersytetu Wrocławskiego, Wrocław 1996 (Acta Universitatis Wratislaviensis No. 1803, Politologia 18).

Romer Eugeniusz, Pamiętnik paryski (1918-1919), oprac. Andrzej Garlicki, Ryszard Świętek, Ossolineum, Wrocław 1989.

Rudnyćkyj Stephan, Der östliche Kriegsschauplatz, Diederichs, Jena 1915.

Rudnyćkyj Stephan, Ukraina und die Ukrainer, Verlag des Allgemeinen Ukrainischen Nationalrats, Wien 1914.

Rudnyćkyj Stephan, Ukraina. Land und Volk. Eine gemeinfassliche Landeskunde, Bund der Befreiung der Ukraina, Wien 1916.

Seegel Steven, Mapping Europe's Borderlands. Russian Cartography in the Age of Empire, University of Chicago Press, Chicago-London 2012.

Seymour Charles, Letters from the Paris Peace Conference, oprac. Harold B. Whiteman, Jr., Yale University Press, New Haven-London 1965.

Sibora Janusz, Dyplomacja polska w I wojnie światowej, PISM, Warszawa 2013.

Sluga Glenda, The Nation, Psychology, and International Politics, 1870-1919, Palgrave, Basingstoke 2006.

Stebelski Ihor, Putting Ukraine on the Map. The Contribution of Stepan Rudnyts'kyi to Ukrainian Nation-Building, „Nationalities Papers” 39, 2011, 4, s. 587-613.

Ter Minassian Talinne, Les géographes français et la délimitation des frontières balkaniques à la conférence de la paix en 1919, „Revue d'histoire moderne et contemporaine" 44, 1997, 2, s. 252-286. 
Żurawski vel Grajewski Przemysław, Sprawa ukraińska na konferencji pokojowej w Paryżu w roku 1919, Semper, Warszawa 1995.

Штойко Павло, Степан Рудницкий 1877-1937. Життеписно - бібліографічний нарис, НТШ, Львів 1993.

Biogram: Maciej Górny, dr hab. prof. IH PAN, redaktor naczelny „Acta Poloniae Historica”; interesuje się historią Europy Środkowo-Wschodniej w XIX i XX w.; kontakt: jmgorny@gmail.com. 